\title{
Evidence for a Direct Reticulocyte Origin of Dense Red Cells in Sickle Cell Anemia
}

Robert M. Bookchin, Olga E. Ortiz, and Virgilio L. Lew*

Department of Medicine, Albert Einstein College of Medicine, Bronx, New York 10461; and

*Physiological Laboratory, Cambridge University, Cambridge, United Kingdom

\begin{abstract}
To explore our hypothesis of a direct reticulocyte origin of irreversibly sickled cells (ISCs), we fractionated light, reticulocyte-rich, and discocyte-rich sickle cell anemia red cells on Stractan gradients, and examined the effects of deoxygenation-induced sickling, external $\mathrm{Ca}^{2+}$, acidification, and replacing external $\mathrm{Na}^{+}$by impermeant $\boldsymbol{N}$-methyl-D-glucamine $\left(\mathrm{NMG}^{+}\right)$. Sickling permeabilized light reticulocyte-rich cells to cations $\left(\mathrm{Na}^{+}, \mathrm{K}^{+}\right.$, and $\left.\mathrm{Ca}^{2+}\right)$ more than discocytes; without external $\mathrm{Ca}^{2+}, \mathrm{Na}^{+}$influx matched $\mathrm{K}^{+}$efflux, with stable cell volume; with $\mathrm{Ca}^{2+}$, many light, low hemoglobin (Hb) $\mathrm{F}$ reticulocytes dehydrated rapidly (preventable by quinine, a $\mathrm{Ca}^{2+}$-dependent $\mathrm{K}^{+}$channel inhibitor). Acidification of oxygenated discocytes (high mean $\mathrm{Hb}$ F) and reticulocyte-rich fractions yielded denser, reticulocyte-enriched cells with lower $\mathrm{Hb}$ F (as in light reticulocyte or dense ISC-rich fractions). Light cells shrank when $\mathrm{NMG}^{+}$replaced $\mathrm{Na}^{+}$, supporting predictions of a $\mathrm{Na}^{+}$-dependent volume control system. Demonstration of sickling-induced, $\mathrm{Ca}^{2+}$-dependent dehydration of $\mathrm{Hb} \mathrm{F}$-free reticulocytes, and conservation of acid-stimulated $\mathrm{K}: \mathrm{Cl}$ cotransport among low $\mathrm{Hb}$ F, reticulocyte-enriched cells in discocyte fractions support the hypothesis. Ancillary new findings included heparin stimulation of sickling-induced $\mathrm{Na}^{+}$and $\mathrm{K}^{+}$permeabilizations, and $\mathrm{Ca}^{2+}$ inhibition of the $\mathrm{Na}^{+}$leak. (J. Clin. Invest. 1991. 87:113-124.) Key words: sickle cell anemia • reticulocyte $\bullet$ red cell dehydration $\bullet$ ion transport $\cdot \mathrm{Ca}^{2+}$
\end{abstract}

\section{Introduction}

The previous paper (1) described a new non-steady-state mathematical model of the volume, $\mathrm{pH}$, and ion content regulation of reticulocytes. The model incorporates the volumeand $\mathrm{pH}$-sensitive $\mathrm{K}: \mathrm{Cl}$ cotransport features recently documented in the light, reticulocyte-enriched fractions of sickle cell anemia (SS) ${ }^{1}$ red blood cells, (RBCs) (2-4). On the basis of the theoretical predictions of that model, together with the previous documentation of the young age of dense irreversibly

A preliminary report of portions of this work was published in abstract form (1988. Clin. Res. 36:613A).

Address correspondence to Dr. Robert M. Bookchin, Department of Medicine, Rm. 913U, Albert Einstein College of Medicine, 1300 Morris Park Avenue, Bronx, NY 10461.

Received for publication 28 August 1989 and in revised form 12 June 1990.

1. Abbreviations used in this paper: $\mathrm{Hb}$, hemoglobin; ISC, irreversibly sickled cell; $\mathrm{NMG}^{+}, \mathrm{N}$-methyl-D-glucamine; $\mathrm{RBC}$, red blood cell; SS, homozygous hemoglobin $\mathrm{S}$ disease, or sickle cell anemia.

J. Clin. Invest.

(c) The American Society for Clinical Investigation, Inc. $0021-9738 / 91 / 113 / 12 \$ 2.00$

Volume 87, January 1991, 113-124 sickled cells (ISCs) (5) and of RBC acidification following $\mathrm{K}^{+}$ permeabilization (6), we developed a new hypothesis on the mechanism of formation of dense SS RBCs. According to this hypothesis $(1,7)$, most ISCs and other dense SS RBCs are primarily generated directly from a fraction of reticulocytes rather than by progressive dehydration of mature discocytes.

The experiments described in this article were designed with the following purposes: $(a)$ to test the feasibility of one of the two basic mechanisms for SS RBC dehydration within the above hypothesis, by determining whether deoxygenation and sickling result in cation $\left(\mathrm{Na}^{+}, \mathrm{K}^{+}, \mathrm{Ca}^{2+}\right)$ permeabilization of the light, reticulocyte-rich fraction of SS cells, and can thereby act as an initial trigger or a part of the positive feedback mechanism for progressive dehydration of the reticulocytes; $(b)$ to examine the effects of any such permeabilization on the volume and density of the cells; $(c)$ to test the model's predicted effects of changes in medium $\mathrm{pH}$ and $\mathrm{Na}^{+}$concentration; $(d)$ to search for the predicted presence of SS RBCs with transport properties of reticulocytes in various density fractions; and $(e)$ to examine whether the experimental procedures that result in dehydration of SS RBC in vitro alter the cell density distribution of hemoglobin $(\mathrm{Hb}) \mathrm{F}$ (which is known to inhibit cell sickling), and thereby help determine the relevance of sickling in SS RBC dehydration in vivo.

\section{Methods}

Composition of solutions. The solutions used contained (in mM): Solution A, $75 \mathrm{NaCl} ; 75 \mathrm{KCl}$; $10 \mathrm{Na}$-Hepes (pH 7.5); $0.1 \mathrm{Na}$-EGTA. Solution B, same as solution A but without Na-EGTA. Solution C, 90 $\mathrm{KCl} ; 60 \mathrm{NaCl}$; $10 \mathrm{Na}$-Hepes (pH 7.5); $0.2 \mathrm{MgCl}_{2} ; 0.02 \mathrm{Na}$-EGTA. Solution D, $5 \mathrm{KCl} ; 145 \mathrm{NaCl} ; 10 \mathrm{Na}-\mathrm{Hepes}$ (pH 7.4 or 7.0); $0.2 \mathrm{MgCl}_{2}$; $0.04 \mathrm{Na}-E G T A$. Solution E, $108 \mathrm{MgCl}_{2} ; 10 \mathrm{Tris}-\mathrm{Cl}\left(\mathrm{pH} 7.4\right.$ at $20^{\circ} \mathrm{C}$ ). "Glucamine medium," $5 \mathrm{KCl} ; 145 \mathrm{~N}$-methyl-glucamine $\left(\mathrm{NMG}^{+}\right)-\mathrm{Cl}$; 10 Tris-Cl; 0.04 Tris-EGTA (either at pH 7.4 or 7.0 at $37^{\circ} \mathrm{C}$ ).

Preparation of cells. Heparinized venous blood was obtained after informed consent from sickle cell anemia patients with established genotype, and kept at $4^{\circ} \mathrm{C}$ for no more than $2 \mathrm{~h}$ before processing. The plasma was separated from the cells after centrifugation at $2,500 \mathrm{~g}$ for $10 \mathrm{~min}$. When needed for later cell resuspension, plasma was spun further at $30,000 \mathrm{~g}$ for $40 \mathrm{~min}$ at $4^{\circ} \mathrm{C}$, decanted, and, after adding 10 $\mathrm{mM}$ inosine and $1 \mathrm{mM}$ adenine, filtered through cellulose acetate membranes with $0.45-\mu \mathrm{m}$ pores (Nalge Co., Rochester, NY) and kept on ice until use. The packed cells were filtered through a nylon mesh (100X polyamide nylon fiber, mesh $20 \mu \mathrm{m}$, Nitex; Tetko Inc., Elmsford, NY) to remove white cells without loss of reticulocytes, washed in solution A, filtered twice more, and finally washed and resuspended in the appropriate incubation medium, or in autologous plasma.

For experiments in heparin-free serum, blood was collected in a syringe containing Na-EGTA (pH 7.4) to give a final concentration of $3.2 \mathrm{mM}$ in the plasma. The plasma was removed and, after addition of $3.2 \mathrm{mM} \mathrm{CaCl} 2$, defibrinated by swirling in a flask containing glass beads before centrifugation and further handling as above.

Density separation procedure. SS RBCs suspended at $40 \%$ hematocrit in solution $\mathrm{A}$ were layered onto discontinuous gradients of arabinogalactan (Stractan II; St. Regis Paper Co., Libby, MT; referred to in 
the text below as Stractan) using a modification (8) of the method of Corash et al. (9). The densities varied with the experimental protocols, as noted below. The cells with $1.000<\delta \leq 1.087$ always had the highest percentage of reticulocytes (as measured by standard procedures after supravital staining with brilliant cresyl blue) and $<1 \%$ white cell contamination. In many experiments a second density layer with $\delta$ between 1.087 and 1.091 was also used as a reticulocyte-rich cell fraction, and additional, higher density layers were used as indicated below to isolate the discocyte-rich cell fractions. The cell fractions were washed three times in solution B and, for experiments done the same day, washed once more and resuspended in the final incubation medium. Alternatively, the cell fractions were kept overnight suspended in solution $\mathrm{C}$ at $4^{\circ} \mathrm{C}$, and before experiments were washed and resuspended in solution $\mathrm{D}$ and incubated for $1 \mathrm{~h}$ at $37^{\circ} \mathrm{C}$. Preliminary experiments indicated that after this procedure the cell ATP content was normal and the cell density and $\mathrm{Na}^{+}$and $\mathrm{K}^{+}$content were essentially the same as they were just after density separation. Finally, the cells were washed three times in solution B and washed once and resuspended in their incubation medium.

The phthalate ester method of Danon and Marikovsky (10) was used, with minor modifications, to compare $\mathrm{RBC}$ density distributions before and after certain experimental protocols. Aliquots of RBC suspension were transferred to microcapillary tubes containing mixtures of diethylphthalate and dibutylphthalate with densities ranging from 1.042 to 1.117 . After 2 min centrifugation at $12,000 \mathrm{rpm}$ in a microhematocrit centrifuge the $\mathrm{Hb}$ content of the pellet was measured and expressed as a percentage of the total $\mathrm{Hb}$ in the aliquot.

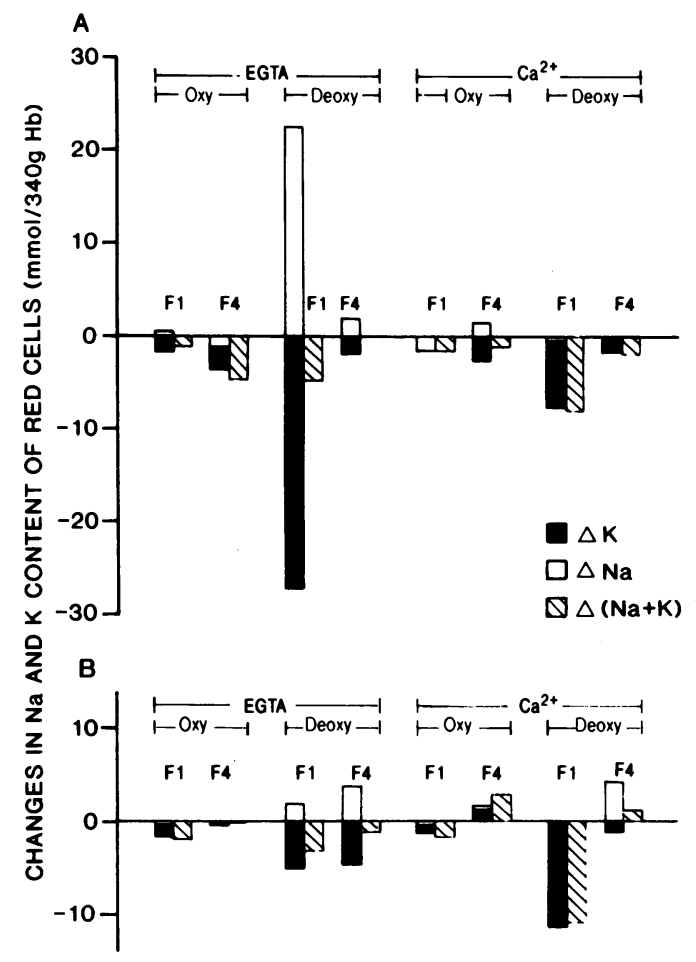

Figure 1. Effect of deoxygenation on the $\mathrm{Na}^{+}$and $\mathrm{K}^{+}$content of SS cell density fractions with different proportions of reticulocytes. Final cell suspension in autologous serum $(10 \% \mathrm{Hct})$, either with normal serum $\mathrm{Ca}^{2+}$ levels or containing $3 \mathrm{mM}$ of EGTA (neutralized with $\mathrm{NaOH})$ to reduce $\left[\mathrm{Ca}^{2+}\right]_{0}$ to submicromolar levels. $A$ and $B$ correspond to experiments with two different donors, and further details are summarized in Table I. $A$ corresponds to donor J.E. in Table I (three density fractions, suspended in serum), and $B$ corresponds to donor A.F. The percent reticulocytes in each fraction are indicated in the table. For both donors the $F 1$ fraction cells had density $\delta$ $\leq 1.087$, and for F4 $1.095<\delta \leq 1.106$.
Deoxygenation of RBCs. RBCs suspended at $10 \% \mathrm{Hct}$ in autologous plasma, serum, or bicarbonate-containing buffers were equilibrated in a tonometer (model 237; Instrumentation Laboratory Inc., Lexington, $\mathrm{MA}$ ) at $37^{\circ} \mathrm{C}$ with humidified $\mathrm{N}_{2}$ or argon containing $5.6 \%$ $\mathrm{CO}_{2}$. Gases without $\mathrm{CO}_{2}$ were used for $\mathrm{RBC}$ suspensions in nonbicarbonate buffers. The suspension pH levels were monitored at $37^{\circ} \mathrm{C}$ (pHM 71 Mk2, and G297/G2 Capillary Electrode; Radiometer, Copenhagen, Denmark) and adjusted to $7.40-7.45$ by addition of 150 $\mathrm{mM} \mathrm{HCl}$ or $\mathrm{NaHCO}_{3}$.

Measurement of $\mathrm{RBC}$ content of $\mathrm{Na}^{+}$and $\mathrm{K}^{+}$. RBCs were washed three times with ice-cold solution E, packed, and lysed in $15 \mathrm{mM} \mathrm{LiCl}$. The $\mathrm{Hb}$ concentration was measured (as cyanmet-Hb) on an aliquot of the lysate, and the $\mathrm{Na}^{+}$and $\mathrm{K}^{+}$concentrations were determined by flame photometry (IL model 143; Instrumentation Laboratory Inc.) and expressed as millimoles per $340 \mathrm{~g} \mathrm{Hb}$.

Measurement of calcium influx into chelator-loaded RBCs. RBCs were preloaded with the high-affinity $\mathrm{Ca}^{2+}$ chelator, Benz2, by the method of Lew et al. (11), in the presence of $5 \mathrm{mM}$ pyruvate to prevent ATP depletion $(12,13)$. The intracellular chelator reduces $\mathrm{Ca}^{2+}$ below levels that activate the $\mathrm{Ca}^{2+}$ pumps (11), so that the rate of increase in total cell calcium can serve as a measure of passive calcium influx with minimal interference from $\mathrm{Ca}^{2+}$ pump extrusion fluxes. The method of Tiffert et al. (12) was used to estimate chelator incorporation and measure influx of ${ }^{45} \mathrm{Ca}$.

Measurement of $\mathrm{Hb} \mathrm{F}$. The percentage of $\mathrm{Hb} F$ in $\mathrm{RBC}$ was estimated, after electrophoresis of the hemolysates on citrate agar gels at pH 6.3 (Corning Medical and Scientific, Palo Alto, CA), by densitometry of the unstained gels. All measurements were made in triplicate or more (except where duplicates were identical to the first decimal) and showed a mean standard error of $0.65 \% \mathrm{Hb} \mathrm{F}$.

Examination of RBC morphology. For examination of RBC morphology before and after various experimental procedures, cell samples were fixed in $10 \%$ formalin in phosphate-buffered (pH 7.4) isotonic saline and later examined with a microscope (Carl Zeiss, Inc., Thornwood, NY) equipped with Nomarski optics.

The percentage of reticulocytes in original blood samples and in density fractions of RBCs before and after incubations was measured by the standard technique of microscopic examination of RBC smears after supravital staining with brilliant cresyl blue.

\section{Results}

Effects of deoxygenation in the presence and absence of external $\mathrm{Ca}^{2+}$ on the $\mathrm{Na}^{+}$and $\mathrm{K}^{+}$content of $\mathrm{SS}$ cell fractions. The two experiments in Fig. 1 compare the extent of sickling-induced $\mathrm{Na}^{+}$and $\mathrm{K}^{+}$permeabilization in the presence and $\mathrm{ab}$ sence of physiological levels of external $\mathrm{Ca}^{2+}$ with two SS cell density fractions: the lightest fraction, highly enriched in reticulocytes; and a fraction with density similar to most normal RBCs, containing much lower proportions of reticulocytes.

During the $30-\mathrm{min}$ incubation at $37^{\circ} \mathrm{C}$ in autologous serum, with added EGTA to chelate all external $\mathrm{Ca}^{2+}$, the light, reticulocyte-rich SS cells (F1) in the experiment in Fig. $1 A$ showed a large deoxygenation-related increase in $\mathrm{Na}^{+}$and $\mathrm{K}^{+}$ leaks, with a small mean net $\mathrm{K}^{+}$loss over $\mathrm{Na}^{+}$gain. Much smaller, balanced $\mathrm{Na}^{+}$and $\mathrm{K}^{+}$leaks occurred during deoxygenation of the discocyte-rich (F4) fraction. Qualitatively similar results were seen with blood from another donor, shown in Fig. $1 B$, where the fluxes induced by deoxygenation of the reticulocyte-rich cells (in the absence of external $\mathrm{Ca}^{2+}$ ) were smaller, and differed little from those of the discocyte fraction. Other similar experiments showed only small flux differences in conditions with and without ouabain, indicating little influence of the sodium pump on these net cation shifts.

In the presence of physiological serum $\mathrm{Ca}^{2+}$ levels, deoxy- 
Table I. Effect of External $\mathrm{Ca}^{2+}$ on the Deoxygenation-induced Changes in the Na and $\mathrm{K}$ Content of Density-fractionated SS RBCs Suspended in Serum or Buffers

\begin{tabular}{|c|c|c|c|c|c|c|c|c|c|c|}
\hline \multirow[b]{4}{*}{ Donor } & \multirow[b]{4}{*}{ Density fraction } & \multirow[b]{4}{*}{ Retics } & \multicolumn{8}{|c|}{$\mathrm{Na}$ and $\mathrm{K}$ content of $\mathrm{RBCs}$} \\
\hline & & & \multirow{2}{*}{\multicolumn{2}{|c|}{ Initial values }} & \multicolumn{6}{|c|}{ Changes after $\mathbf{3 0}$ min deoxygenation } \\
\hline & & & & & \multicolumn{3}{|c|}{ Excess EGTA } & \multicolumn{3}{|c|}{$1.2 \mathrm{mM} \mathrm{Ca}^{2+}$} \\
\hline & & & $\mathbf{N a}$ & $\mathbf{K}$ & $\Delta \mathrm{Na}$ & $\Delta \mathbf{K}$ & $\Delta(\mathrm{Na}+\mathrm{K})$ & $\Delta \mathrm{Na}$ & $\Delta \mathbf{K}$ & $\Delta(\mathrm{Na}+\mathrm{K})$ \\
\hline & & $\%$ & \multicolumn{8}{|c|}{$\mathrm{mmol} / 340 \mathrm{~g} \mathrm{Hb}$} \\
\hline J.N.* & $\delta \leq 1.087$ & 53 & 29.7 & 126 & +5.7 & -10.9 & -5.2 & +2.6 & -11.6 & -9.0 \\
\hline T.N.* & $1.087<\delta \leq 1.091$ & 70 & 17.4 & 114 & +6.9 & -10.7 & -3.8 & +7.0 & -10.3 & -3.3 \\
\hline J.E..$^{\ddagger}$ & $\delta \leq 1.087$ & 60 & 9.5 & 148 & +1.9 & -8.3 & -6.4 & -1.5 & -2.9 & -4.4 \\
\hline J.E. ${ }^{8}$ & $\delta \leq 1.087$ & 60 & 9.5 & 148 & +1.9 & -7.6 & -5.7 & -1.8 & -9.1 & -10.9 \\
\hline B.W. & $\delta \leq 1.091$ & 57 & 9.7 & 138 & +18.7 & -20.7 & -2.0 & +11.8 & -21.9 & -10.1 \\
\hline \multirow[t]{3}{*}{ A.F." } & $\delta \leq 1.087$ & 50 & 14.7 & 132 & +1.7 & -4.9 & -3.5 & +0.3 & -10.9 & -10.6 \\
\hline & $1.087<\delta \leq 1.091$ & 26 & 34.1 & 105 & -0.1 & -2.4 & -2.5 & +4.2 & -2.8 & +1.4 \\
\hline & $1.095<\delta \leq 1.106$ & 5 & 12.8 & 96 & +3.7 & -4.6 & -0.9 & +3.4 & -1.0 & +2.4 \\
\hline \multirow[t]{3}{*}{ J.E." } & $\delta \leq 1.087$ & 64 & 10.0 & 129 & +22.5 & -27.0 & -4.5 & -0.4 & -7.5 & -7.9 \\
\hline & $1.087<\delta \leq 1.091$ & 39 & 8.3 & 108 & +3.9 & -4.5 & -0.6 & +1.3 & -0.3 & +1.0 \\
\hline & $1.095<\delta \leq 1.106$ & 20 & 13.7 & 87 & +1.9 & -1.9 & 0.0 & -0.4 & -1.6 & -2.0 \\
\hline
\end{tabular}

SS RBCs with the densities shown were suspended in autologous serum or buffer as noted at $10 \%$ Hct, with or without added EGTA (to give nominally $\mathrm{Ca}^{2+}$-free plasma). For cell suspensions in buffers, sufficient $\mathrm{CaCl}_{2}$ was added to give $\sim 1.2 \mathrm{mM} \mathrm{Ca}^{2+}$ in the presence of the corresponding amounts of albumin. The mean content of $\mathrm{RBC}$ Na and $\mathrm{K}$ in each sample was measured before and after incubation at $37^{\circ} \mathrm{C}$ with 30 min deoxygenation and $5 \mathrm{~min}$ reoxygenation. Gases for deoxygenation and reoxygenation of serum and bicarbonate buffers contained $5.6 \% \mathrm{CO}_{2}$. * Suspended in buffer containing $5.0 \mathrm{~g} / \mathrm{dl}$ of bovine serum albumin and (in mM) $5 \mathrm{KCl}, 145 \mathrm{NaCl}, 10 \mathrm{Na}-\mathrm{HEPES}$ (pH 7.40), 1.0 adenosine, 10 inosine, 10 glucose, and $0.2 \mathrm{MgCl}_{2}$ (adjusted to $300 \mathrm{mosmol} / \mathrm{kg} \mathrm{H}_{2} \mathrm{O}$ ). ${ }^{\ddagger}$ Suspended in buffer containing $4.0 \mathrm{~g} / \mathrm{dl}$ of bovine serum albumin and (in mM) $5 \mathrm{KCl}, 127 \mathrm{NaCl}, 1.0 \mathrm{MgCl}_{2}, 1.2 \mathrm{NaH}_{2} \mathrm{PO}_{4}$, (total osmolality $299 \mathrm{mosmol} / \mathrm{kg} \mathrm{H}_{2} \mathrm{O}$ ). ${ }^{\S}$ Suspended in buffer of the same composition as ${ }^{\ddagger}$ (above) except that $27 \mathrm{mmol} / \mathrm{liter}$ of $\mathrm{NaCl}$ was replaced by equimolar $\mathrm{NaHCO}_{3}$. "Suspended in serum.

Table II. Effect of External $\mathrm{Ca}^{2+}$ on the Deoxygenation-induced Changes in the Na and $\mathrm{K}$ Content of Density-fractionated SS RBCs Suspended in Heparinized Plasma

\begin{tabular}{|c|c|c|c|c|c|c|c|c|c|c|}
\hline \multirow[b]{4}{*}{ Donor } & \multirow[b]{4}{*}{ Density fraction } & \multirow[b]{4}{*}{ Retics } & \multicolumn{8}{|c|}{$\mathrm{Na}$ and $\mathrm{K}$ content of $\mathrm{RBCs}$} \\
\hline & & & & & \multicolumn{6}{|c|}{ Changes after $30 \mathrm{~min}$ deoxygenation } \\
\hline & & & \multicolumn{2}{|c|}{ Initial values } & \multicolumn{3}{|c|}{ Excess EGTA } & \multicolumn{3}{|c|}{$1.2 \mathrm{mM} \mathrm{Ca}^{2+}$} \\
\hline & & & $\mathrm{Na}$ & $\mathbf{K}$ & $\Delta \mathrm{Na}$ & $\Delta \mathbf{K}$ & $\Delta(\mathrm{Na}+\mathrm{K})$ & $\Delta \mathrm{Na}$ & $\Delta \mathbf{K}$ & $\Delta(\mathrm{Na}+\mathrm{K})$ \\
\hline & & $\%$ & \multicolumn{8}{|c|}{$m m o l / 340 \mathrm{~g} \mathrm{Hb}$} \\
\hline M.M. & $\delta \leq 1.091$ & 78 & 15.6 & 143 & +11.1 & -11.9 & -0.8 & +4.4 & -7.6 & -3.2 \\
\hline M.M. & $\delta \leq 1.091$ & 63 & 9.7 & 124 & +8.0 & -8.8 & -0.8 & +3.7 & -8.3 & -4.6 \\
\hline M.M. & $\delta \leq 1.087$ & - & 13.3 & 125 & +8.2 & -9.5 & -1.3 & +3.3 & -8.1 & -4.8 \\
\hline M.M. & $1.087<\delta \leq 1.091$ & 50 & 9.0 & 122 & +4.1 & -6.6 & -2.5 & -0.7 & -1.0 & -1.7 \\
\hline J.E. & $\delta \leq 1.087$ & 56 & 9.6 & 142 & +16.4 & -17.1 & -0.7 & +8.1 & -20.3 & -12.2 \\
\hline J.E. & $\delta \leq 1.087$ & 53 & 12.5 & 135 & +18.1 & -16.6 & +1.5 & +15.2 & -21.4 & -6.2 \\
\hline J.E. & $\delta \leq 1.087$ & 60 & 9.5 & 148 & +13.1 & -20.9 & -7.8 & +2.0 & -2.6 & -0.6 \\
\hline T.N. & $1.087<\delta \leq 1.091$ & 70 & 17.4 & 114 & +24.1 & -23.3 & +0.8 & +10.1 & -16.4 & -6.3 \\
\hline K.W. & $\delta \leq 1.091$ & 64 & 20.1 & 122 & +45.7 & -47.9 & -2.2 & +27.7 & -33.8 & -6.1 \\
\hline B.W. & $\delta \leq 1.091$ & 57 & 9.7 & 138 & +53.9 & -54.2 & -0.3 & +14.6 & -20.2 & -5.6 \\
\hline \multirow[t]{3}{*}{ A.F. } & $\delta \leq 1.087$ & 67 & 21.7 & 124 & +15.9 & -19.1 & -3.2 & +2.1 & -4.7 & -2.6 \\
\hline & $1.087<\delta \leq 1.091$ & 47 & 9.4 & 115 & +7.9 & -6.1 & +1.8 & +2.8 & -3.5 & -0.7 \\
\hline & $1.091<\delta \leq 1.095$ & 9 & 13.0 & 96 & +5.1 & -5.3 & -0.2 & +5.3 & -5.2 & +0.1 \\
\hline
\end{tabular}

SS RBCs with the densities shown were suspended in autologous plasma at $10 \%$ Hct with or without added EGTA (to give nominally $\mathrm{Ca}^{2+}$-free plasma). The mean content of $\mathrm{RBC} \mathrm{Na}$ and $\mathrm{K}$ in each sample was measured before and after incubation at $37^{\circ} \mathrm{C}$ with 30 min deoxygenation and 5 min reoxygenation. 
genation of the reticulocyte-rich (F1) fractions in both experiments of Fig. 1 induced potassium leaks with little or no sodium leaks, so that mean net cation losses predominated. In the experiment in Fig. $1 A$ it is not possible to distinguish whether the net $\mathrm{K}^{+}$loss in the presence of $\mathrm{Ca}^{2+}$ resulted from activation of the $\mathrm{K}^{+}$(Gardos) channel or from greater inhibition of the $\mathrm{Na}^{+}$leak than the $\mathrm{K}^{+}$leak induced by deoxygenation. In the Fig. $1 B$ experiment, however, the $\mathrm{K}^{+}$leak on deoxygenation of the light cell fraction was actually larger in the presence of $\mathrm{Ca}^{2+}$, suggesting $\mathrm{K}^{+}$channel activation.

Table I shows the details of several experiments similar to (and including) those in Fig. 1, with the RBCs incubated in either serum or albumin-containing buffers. In most instances, the mean net cation shifts included smaller $\mathrm{Na}^{+}$gains and larger $\mathrm{K}^{+}$losses when external $\mathrm{Ca}^{2+}$ was present. Experiments with one donor (J.E.) showed no differences in the sickling-induced fluxes in the presence or absence of bicarbonate.
Interrelated effects of heparin and $\mathrm{Ca}^{2+}$ on sickling-induced $\mathrm{Na}$ and $\mathrm{K}$ leaks. The experiments in Table II are grouped together because they were all done with RBCs suspended in plasma containing heparin. In these conditions, at very low external $\mathrm{Ca}^{2+}$ (with excess EGTA), the deoxygenation-induced changes in $\mathrm{Na}^{+}$and $\mathrm{K}^{+}$content after 30 min were generally much larger than those in the absence of heparin (only with the light, reticulocyte-rich fractions), and fairly balanced. Other experiments (not shown here since they are part of a separate study) indicated that heparin per se stimulated the sickling-induced $\mathrm{Na}^{+}$and $\mathrm{K}^{+}$leaks in this cell fraction. External $\mathrm{Ca}^{2+}$ reduced the deoxygenation-induced leaks of both $\mathrm{Na}^{+}$and $\mathrm{K}^{+}$ but, as in the heparin-free experiments, $\mathrm{Na}^{+}$gain was inhibited considerably more than $\mathrm{K}^{+}$loss. Therefore, the presence of physiological $\mathrm{Ca}^{2+}$ concentrations in the medium resulted in significant net cation loss despite the lower overall magnitude of the deoxygenation-induced leaks. A control experiment

Table III. Effects of External $\mathrm{Ca}^{2+}$ and Dexoygenation of the Reticulocyte-rich Fraction of SS RBCs on Their Density Distribution and Na and K Contents

\begin{tabular}{|c|c|c|c|c|c|c|c|c|c|c|c|}
\hline \multirow[b]{3}{*}{ Donor } & \multirow[b]{3}{*}{ Retics } & \multirow[b]{3}{*}{$\begin{array}{c}\text { Stractan } \\
\text { density } \\
(\delta)\end{array}$} & & & & \multicolumn{6}{|c|}{ After $30 \mathrm{~min}$ deoxygenation } \\
\hline & & & \multicolumn{3}{|c|}{ Initial values } & \multicolumn{3}{|c|}{ Excess EGTA } & \multicolumn{3}{|c|}{$1.2 \mathrm{mM} \mathrm{Ca}^{2+}$} \\
\hline & & & $\begin{array}{c}\text { RBC with } \\
\delta>\text { Stractan }\end{array}$ & $\mathrm{Na}$ & $\mathbf{K}$ & $\begin{array}{c}\text { RBC with } \\
\delta>\text { Stractan }\end{array}$ & $\mathrm{Na}$ & $\mathbf{K}$ & $\begin{array}{c}\text { RBC with } \\
\delta>\text { Stractan }\end{array}$ & $\mathrm{Na}$ & $\mathbf{K}$ \\
\hline & $\%$ & & $\%$ & \multicolumn{2}{|c|}{$\mathrm{mmol} / 340 \mathrm{~g} \mathrm{Hb}$} & $\%$ & \multicolumn{2}{|c|}{$\mathrm{mmol} / 340 \mathrm{~g} \mathrm{Hb}$} & $\%$ & \multicolumn{2}{|c|}{$\mathrm{mmol} / 340 \mathrm{~g} \mathrm{Hb}$} \\
\hline \multirow[t]{6}{*}{ A.F.* } & 67 & 1.000 & 100 & 21.7 & 124 & 100 & 37.6 & 105 & 100 & 20.8 & 116 \\
\hline & & 1.074 & 92 & 13.2 & 126 & 77 & 21.8 & 114 & 92 & 14.8 & 117 \\
\hline & & 1.083 & 71 & 9.3 & 126 & 53 & 14.5 & 11 & 70 & 11.1 & 116 \\
\hline & & 1.087 & 49 & 9.1 & 125 & 35 & 13.0 & 120 & 52 & 11.4 & 112 \\
\hline & & 1.091 & 8 & 7.1 & 118 & 7 & 11.2 & 115 & 24 & 14.7 & 103 \\
\hline & & 1.095 & 0 & - & - & 0 & - & - & 5 & 30.3 & 83 \\
\hline \multirow[t]{6}{*}{ K.W.* } & 64 & 1.000 & 100 & 19.2 & 128 & 100 & 64.9 & 75 & 100 & 48.6 & 83 \\
\hline & & 1.074 & 89 & 12.1 & 122 & 63 & 33.8 & 81 & 89 & 45.1 & - \\
\hline & & 1.083 & 73 & 9.4 & - & 49 & 29.6 & 96 & 83 & 44.2 & 89 \\
\hline & & 1.087 & 24 & 8.5 & 102 & 13 & 27.9 & 77 & 61 & 45.9 & 65 \\
\hline & & 1.091 & 0 & - & - & 2 & - & - & 50 & 47.1 & 61 \\
\hline & & 1.095 & 0 & - & - & 0 & - & - & 38 & 47.4 & 64 \\
\hline \multirow[t]{5}{*}{ J.E.* } & 60 & 1.000 & 100 & 9.5 & 148 & 100 & 22.5 & 127 & 100 & 11.4 & 145 \\
\hline & & 1.079 & 82 & 9.0 & 142 & 82 & 15.0 & 126 & 89 & 10.6 & 139 \\
\hline & & 1.083 & 38 & 7.6 & 133 & 52 & 14.2 & 126 & 64 & 11.5 & 129 \\
\hline & & 1.087 & 0 & - & - & 20 & 17.1 & 121 & 27 & 13.9 & 114 \\
\hline & & 1.091 & 0 & - & - & 6 & - & - & 15 & 17.9 & 109 \\
\hline \multirow[t]{5}{*}{ J.E. ${ }^{\ddagger}$} & 60 & 1.000 & 100 & 9.5 & 148 & 100 & 11.4 & 141 & 100 & 9.6 & 139 \\
\hline & & 1.079 & 82 & 9.0 & 142 & 84 & 10.8 & 137 & 92 & 9.8 & 134 \\
\hline & & 1.083 & 38 & 7.6 & 133 & 63 & 9.3 & 134 & 65 & 9.7 & 132 \\
\hline & & 1.087 & 0 & - & - & 23 & 8.4 & 131 & 32 & 10.0 & 128 \\
\hline & & 1.091 & 0 & - & - & 4 & - & - & 17 & 10.4 & 121 \\
\hline \multirow[t]{3}{*}{ B.W.* } & 57 & 1.000 & 100 & 9.7 & 138 & 100 & 63.6 & 83 & 100 & 24.3 & 117 \\
\hline & & 1.079 & 100 & 9.7 & 138 & 71 & 31.6 & 111 & 100 & 24.3 & 117 \\
\hline & & 1.091 & 9 & - & - & 16 & - & - & 50 & 28.2 & 99 \\
\hline \multirow[t]{3}{*}{ B.W..$^{\ddagger}$} & 57 & 1.000 & 100 & 9.6 & 138 & 100 & 28.4 & 122 & 100 & 21.5 & 116 \\
\hline & & 1.079 & 100 & 9.6 & 138 & 82 & 17.3 & 134 & 98 & 18.4 & 119 \\
\hline & & 1.091 & 5 & - & - & 19 & - & - & 46 & 27.3 & 108 \\
\hline
\end{tabular}

SS RBCs from each of the density fractions shown were suspended at $10 \% \mathrm{Hct}$ in the media shown with or without added EGTA (to give nominally $\mathrm{Ca}^{2+}$-free plasma). See legend of Table $\mathrm{I}$ for addition of calcium to buffers. The mean content of $\mathrm{RBC} \mathrm{Na}$ and $\mathrm{K}$ in each sample was measured in each density fraction before and after incubation at $37^{\circ} \mathrm{C}$ with $30 \mathrm{~min}$ deoxygenation and 5 min reoxygenation. * Suspended in heparinized plasma. ${ }^{\ddagger}$ Suspended in buffer containing $4.0 \mathrm{~g} / \mathrm{dl}$ bovine serum albumin and (in mM) $5 \mathrm{KCl}, 100 \mathrm{NaCl}, 27 \mathrm{NaHCO}_{3}, 1.0 \mathrm{MgCl}_{2}, 1.2$ $\mathrm{NaH}_{2} \mathrm{PO}_{4}$, (total osmolality $299 \mathrm{mosmol} / \mathrm{kg} \mathrm{H}_{2} \mathrm{O}$ ). 
(not shown) in which Ca-EGTA was added to the plasma, leaving normal plasma $\mathrm{Ca}^{2+}$, showed no difference from the results with plasma $\mathrm{Ca}^{2+}$ alone, thereby excluding the possibility that the effect of EGTA was due to chelation of trace amounts of another heavy metal.

The effects of $\mathrm{Ca}^{2+}$ on the sickling-induced leaks are more evident in Table III, which shows the cation contents of each of the new density fractions formed after deoxygenation of the original light, reticulocyte-rich SS RBCs. In each experiment
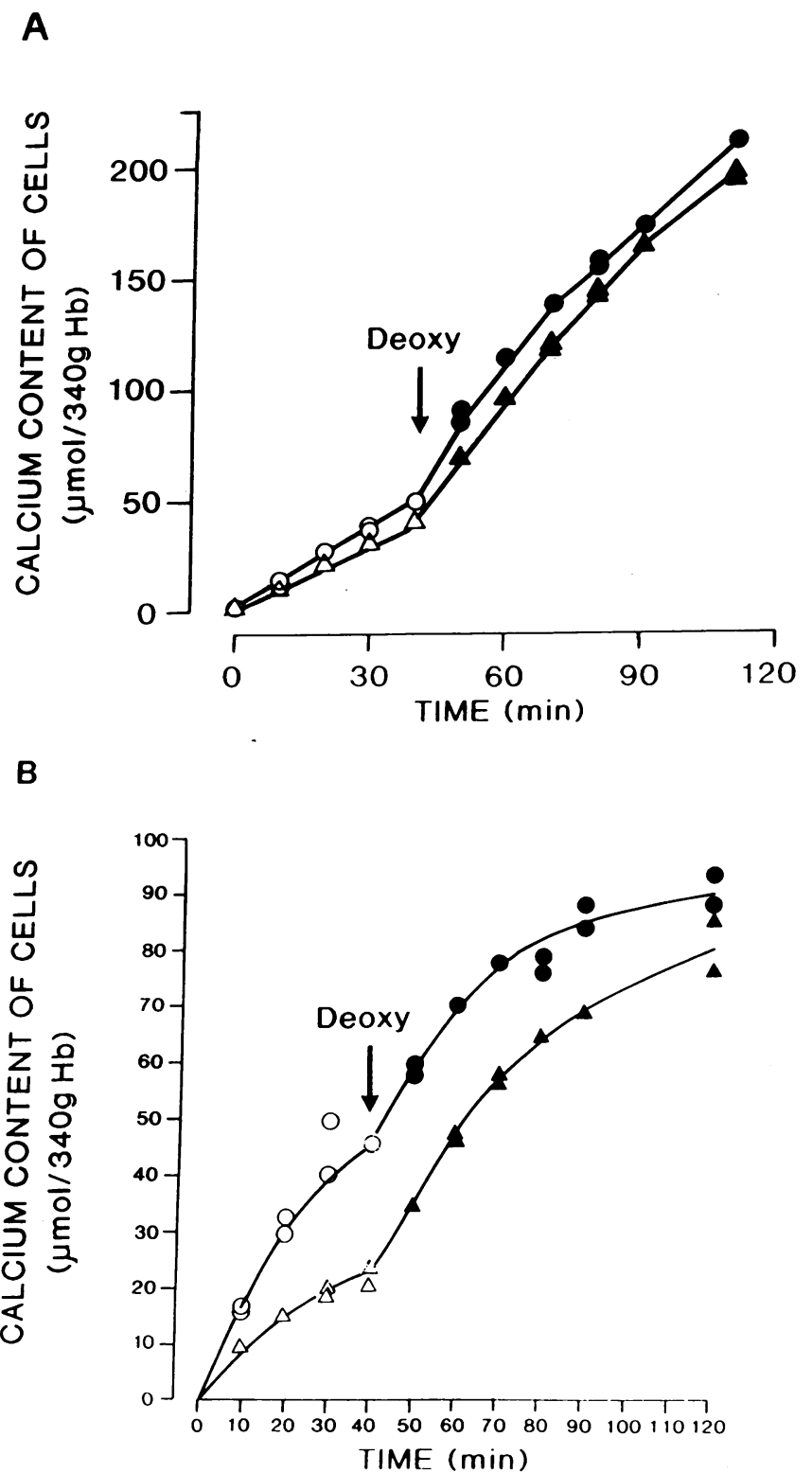

Figure 2. Effect of deoxygenation on ${ }^{45} \mathrm{Ca}$ uptake by density fractions of SS RBCs loaded with the calcium chelator Benz2. The RBCs were suspended at $10 \% \mathrm{Hct}$ in autologous plasma. Each panel shows an experiment with RBCs from a separate donor, and two density fractions, $1.087<\delta<1.091$ (circles) and $1.095<\delta \leq 1.106$ (triangles). The percentages of reticulocytes in the lighter and heavier fractions were 28 and $2 \%$, respectively, in $A$, and 64 and $10 \%$ in $B$. Intracellular Benz2 concentrations, in millimoles/liter of cells, were 4.2 and 3.6 , respectively, for reticulocytes and disocytes in the experiment in $A$, and 0.23 and 0.074 in the experiment in $B$. (with or without heparin), $\mathrm{Ca}^{2+}$ induced the formation of large numbers of denser cells, and these newly dense cells showed the most dramatic net $\mathrm{K}^{+}$loss, exceeding their $\mathrm{Na}^{+}$gain.

In all of these experiments there were considerable variations between donors in the size of the net cation shifts, and sometimes in different experiments with the blood samples from the same donor.

Effect of deoxygenation on the calcium uptake by chelatorloaded SS cells. The uptake of $\mathrm{Ca}^{2+}$ by SS discocytes and by reticulocyte-rich SS cell fractions was investigated after loading the cells with a chelator to maintain cytoplasmic $\mathrm{Ca}^{2+}$ below levels that activate the calcium pump. In this condition $\mathrm{Ca}^{2+}$ influx measures passive inward leak. Fig. 2 shows that, in agreement with early studies (14), passive calcium uptake in oxygenated reticulocytes is higher than in discocytes, and that

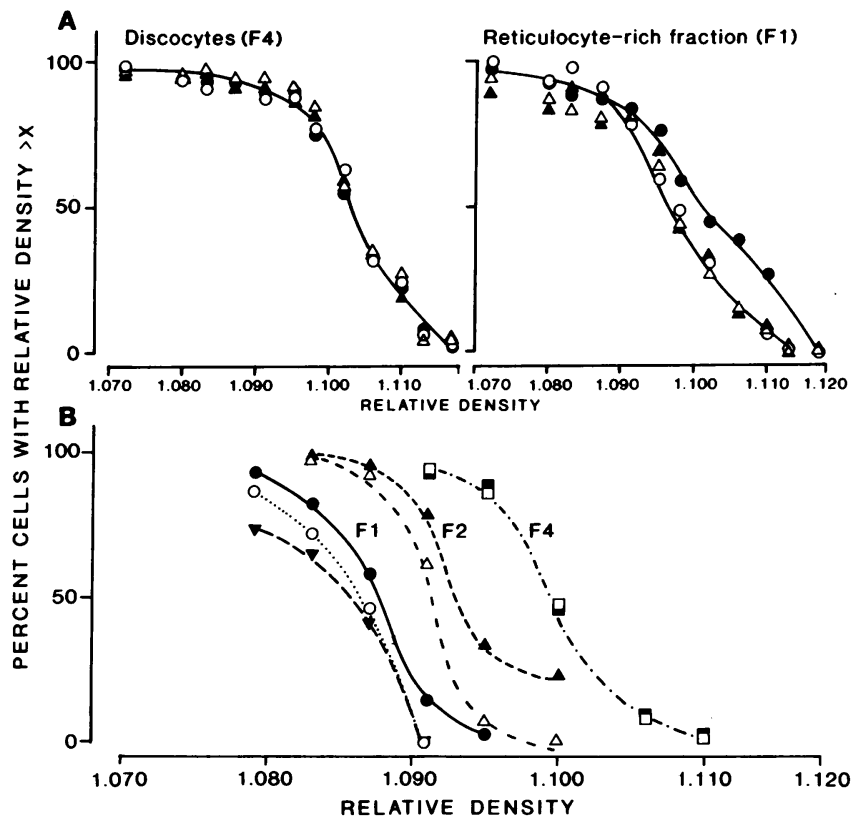

Figure 3. Effect of deoxygenation and external $\mathrm{Ca}^{2+}$ on the density distribution of SS discocytes and light, reticulocyte-rich fractions of SS RBCs. $(A)$ This experiment used two fractions of SS RBCs obtained from Stractan gradients: $F 1$, a fraction with density $\delta \leq 1.087$, containing $61 \%$ reticulocytes; and $\mathrm{F} 4$, a discocyte-rich fraction with density $1.095<\delta \leq 1.105$, containing $18 \%$ reticulocytes. The RBCs were suspended at $20 \%$ Hct in autologous heparinized plasma, with or without addition of $3 \mathrm{mM}$ EGTA, and equilibrated in a tonometer at $37^{\circ} \mathrm{C}$ with the appropriate gas mixture (see Methods); for this experiment, "oxy" equilibration was in $5.6 \% \mathrm{CO}_{2}$ in oxygen, and "deoxy" equilibration was with the above oxygen mixture for $5 \mathrm{~min}$ alternating with $5.6 \% \mathrm{CO}_{2}$ in argon for $20 \mathrm{~min}$. After $55 \mathrm{~min}$ incubation the density distribution of each $\mathrm{RBC}$ suspension was measured using phthalate esters (see Methods). $\Delta$, oxy, EGTA; $\Delta$, deoxy, EGTA; O, oxy, $\mathrm{Ca}^{2+}$ present; $\bullet$, deoxy, $\mathrm{Ca}^{2+}$ present. (B) Three Stractan density fractions of SS RBCs were used in this experiment: F1, with $\delta \leq 1.087$ and $64 \%$ reticulocytes; F2, $1.087<\delta \leq 1.091$, with $39 \%$ reticulocytes; and $\mathrm{F} 4,1.095 \leq \delta<1.106$, with $20 \%$ reticulocytes. The RBCs were suspended in autologous serum and the incubations were performed as in $A$ (above) except that the period of deoxy incubation was $30 \mathrm{~min}$. The density distribution of each suspension was redetermined using the same Stractan solutions as for the initial separations. For $\mathrm{F} 1$ : $\mathrm{O}$, initial; •, deoxy, $\mathrm{Ca}^{2+}$ present; $\nabla$, deoxy, EGTA; for F2: $\triangle$, initial; $\triangle$, deoxy, $\mathrm{Ca}^{2+}$ present; for $\mathrm{F} 4$, 口, initial; $\mathbf{a}$, deoxy, $\mathrm{Ca}^{2+}$ present. 
deoxygenation markedly increases calcium influx. Thus, as with SS discocytes, the deoxygenation-induced increase in SS reticulocyte permeability apparently affects at least $\mathrm{Na}^{+}, \mathrm{K}^{+}$, and $\mathrm{Ca}^{2+}$, and may be nonselective to small ions in general.

Effects of deoxygenation and external $\mathrm{Ca}^{2+}$ on the density distribution of SS discocytes and reticulocytes. The experiments of Fig. 3 show that when SS discocytes and reticulocyte-rich cells were suspended in either autologous heparinized plasma or autologous serum and incubated at $37^{\circ} \mathrm{C}$ for $30-55$ min, an increase in cell density was seen only with the light, high reticulocyte cell fractions, and only when the cells were deoxygenated in the presence of $\mathrm{Ca}^{2+}$. There was a consistent enrichment in the proportion of reticulocytes among the cells that became dense when deoxygenated in the presence of $\mathrm{Ca}^{2+}$. This is seen in a similar experiment in Table IV, which shows the effects of external $\mathrm{Ca}^{2+}$ and of deoxygenation on the density and reticulocyte redistribution of a light, reticulocyte-rich SS RBC fraction. Upon incubation in serum for $30 \mathrm{~min}$, an increase in cell density occurred in a substantial fraction of cells only in the deoxygenated condition with physiological levels of serum $\mathrm{Ca}^{2+}$, and nearly all the cells that increased in density were reticulocytes.

In a separate, similar experiment (not shown), after deoxygenation of a reticulocyte-rich fraction of SS RBCs $(\delta<1.087)$ for $30 \mathrm{~min}$ in the presence of $\mathrm{Ca}^{2+}$, the morphology of the newly dehydrated cells was examined after further density fractionation. Each of these fractions showed an increase in the proportion of cells with the convoluted membrane surfaces typical of "stress reticulocytes" (from 13\% of the original light cells to $23-33 \%$ of denser fractions), and an increased number of small, deformed cells typical of dense non-ISCs from fresh SS blood. But a small fraction, comprising the densest of the newly dehydrated cells $(\delta>1.100)$, showed $\sim 20 \%$ of cells whose length was at least twice their width, and had the appearance of relatively short, fat ISCs.

These results show that, in contrast to the behavior of SS discocytes, many of the cells in the light, reticulocyte-rich SS

Table IV. Effects of External $\mathrm{Ca}^{2+}$ and Deoxygenation on the Density and Reticulocyte Redistribution of a Light, Reticulocyte-rich Fraction of SS RBCs

\begin{tabular}{|c|c|c|c|c|}
\hline \multirow[b]{2}{*}{ Sample } & \multicolumn{2}{|c|}{$\delta<1.087$} & \multicolumn{2}{|c|}{$\delta>1.087$} \\
\hline & $\begin{array}{l}\text { Percent of } \\
\text { total RBC }\end{array}$ & $\begin{array}{c}\text { Percent } \\
\text { reticulocytes }\end{array}$ & $\begin{array}{l}\text { Percent of } \\
\text { total RBC }\end{array}$ & $\begin{array}{c}\text { Percent } \\
\text { reticulocytes }\end{array}$ \\
\hline Initial & 100 & 46 & 0 & - \\
\hline Oxy + EGTA & 99 & 39 & 1 & 100 \\
\hline Deoxy + EGTA & 99 & 48 & 1 & 100 \\
\hline $\mathrm{Oxy}+\mathrm{Ca}^{2+*}$ & 99 & 39 & 1 & 100 \\
\hline Deoxy $+\mathrm{Ca}^{2+*}$ & 90 & 46 & 10 & 95 \\
\hline
\end{tabular}

A fraction of RBCs with density $\delta \leq 1.087$, containing $\sim 45 \%$ reticulocytes, was suspended at $20 \%$ Hct in autologous serum with or without addition of $3 \mathrm{mM}$ EGTA. After $30 \mathrm{~min}$ incubation at $37^{\circ} \mathrm{C}$ in either $5.6 \% \mathrm{CO}_{2}$ with oxygen (oxy) or argon (deoxy) $0.5 \mathrm{ml}$ of the suspension was layered onto a discontinuous gradient of seven density layers of Stractan to determine the RBC density distribution. Only after the Deoxy $+\mathrm{Ca}^{2+}$ incubation did some cells (reticulocytes) achieve densities greater than 1.095 and 1.100 .

* Original serum levels of $\mathrm{Ca}^{2+}$. fractions dehydrate rapidly when deoxygenated in the presence of plasma levels of $\mathrm{Ca}^{2+}$. Most of these newly dehydrated cells are reticulocytes, including an enrichment in "stress reticulocytes," but the fraction that becomes dense and the proportion of reticulocytes within it vary from patient to patient. Even after brief incubation under these conditions, a small number of cells meet the morphological criteria of ISCs.

Effects of quinine on the changes in density of reticulocyterich SS cell fractions induced by deoxygenation in the presence and absence of $\mathrm{Ca}^{2+}$. To help discern a possible role of the $\mathrm{Ca}^{2+}$-dependent $\mathrm{K}^{+}$channel in unbalancing the $\mathrm{Na}^{+}$and $\mathrm{K}^{+}$ leaks when reticulocyte-rich SS cell fractions were deoxygenated in the presence of external $\mathrm{Ca}^{2+}$, we examined the effects of addition of quinine, a well characterized (although nonspe-
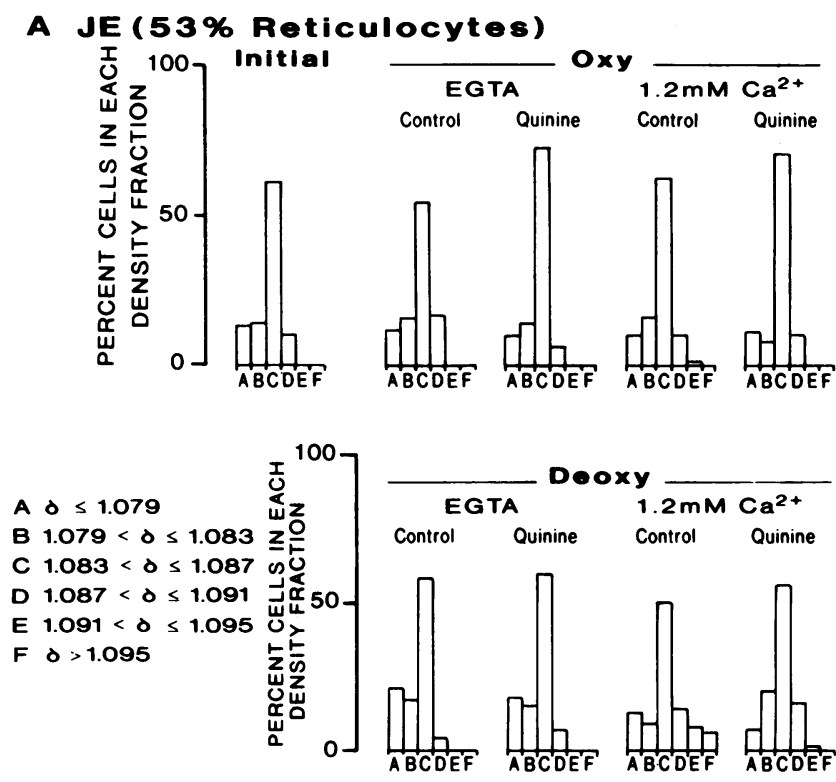

B KW (64\% Reticulocytes)

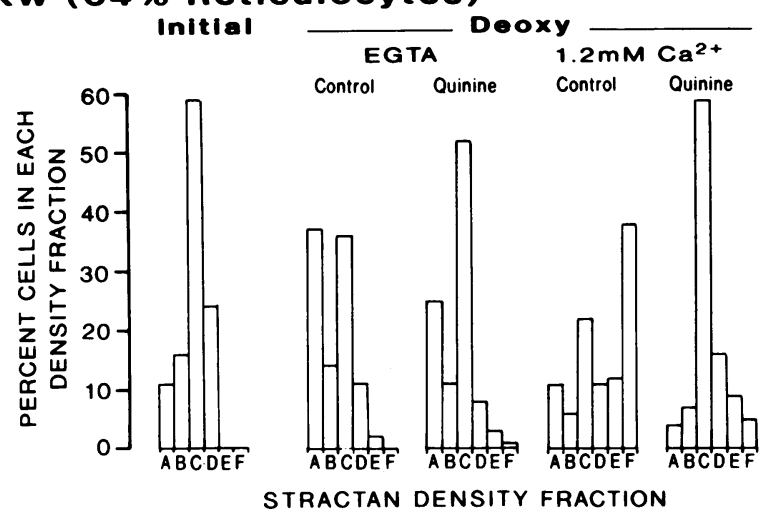

Figure 4. Effects of quinine, $\mathrm{Ca}^{2+}$, and deoxygenation on the density redistribution of a light, reticulocyte-rich fraction of SS RBCs. Two experiments are shown in which RBC fractions with density $\delta$ $\leq 1.087$ were suspended at $20 \%$ Hct in autologous plasma with or without addition of $3 \mathrm{mM}$ EGTA and with or without $1 \mathrm{mM}$ quinine hydrochloride. After $30 \mathrm{~min}$ incubation at $37^{\circ} \mathrm{C}$ in either $5.6 \%$ $\mathrm{CO}_{2}$ with oxygen (oxy) or argon (deoxy), $0.5 \mathrm{ml}$ of the suspension was layered onto a discontinuous gradient of Stractan (densities shown), and the percentage of cells (measured as percent $\mathrm{Hb}$ ) in each density fraction was determined. 
cific) inhibitor of $\mathrm{Ca}^{2+}$-activated $\mathrm{K}^{+}$channels in red cells (15). As shown in the two experiments in Fig. 4, with oxygenated cells with or without $\mathrm{Ca}^{2+}$, or with deoxygenated cells in the absence of $\mathrm{Ca}^{2+}$, a small and variable fraction of cells became more dense in the presence of quinine. For RBCs deoxygenated with $1.2 \mathrm{mM} \mathrm{Ca}^{2+}$ in the medium, however, the fraction of cells that became more dense was greatly reduced when quinine was present. Thus, quinine prevented an increase in cell density only when it was induced by deoxygenation and $\mathrm{Ca}^{2+}$. These results suggest that when reticulocyte-rich SS RBCs are sickled in the presence of $\mathrm{Ca}^{2+}, \mathrm{K}^{+}$channels are activated and participate in the cell dehydration.

Effects of acidification and $\mathrm{Na}^{+}$replacement on the density distribution of SS cells. To test the reticulocyte model's predicted requirement of a high $\mathrm{Na}^{+}$influx to maintain the normal volume of reticulocytes, and to see if there were cells with an active $\mathrm{K}: \mathrm{Cl}$ cotransport that could be stimulated by low cell pH, oxygenated, reticulocyte-rich SS cells were incubated either at lowered pH (from 7.4 to 7.0) or in media in which external $\mathrm{Na}^{+}$was replaced by the monovalent cation $\mathrm{NMG}^{+}$, commonly considered impermeant. The results in Table $\mathrm{V}$ and Fig. 5 show that with each of these maneuvers a proportion of cells became more dense. $\mathrm{Na}^{+}$replacement had no significant effects on the density distribution of normal RBCs within the same period (not shown).

The presence of $20 \mathrm{mM} \mathrm{Na}^{+}$in the media of experiment I in Table $\mathrm{V}$ may account for the smaller dehydrating effect of $\mathrm{NMG}^{+}$in this experiment than in experiments II and III, in which $\mathrm{Na}^{+}$was completely replaced by $\mathrm{NMG}^{+}$. In the latter two experiments, in which a substantial fraction of RBCs became denser in glucamine media at $\mathrm{pH} 7.4$, that denser fraction was maximal at 30 min incubation and then decreased. Also, the effects of combining low $\mathrm{pH}$ and $\mathrm{Na}^{+}$replacement were not additive. Both of these findings could result if the reticulocytes were somewhat permeable to $\mathrm{NMG}^{+}$. In Fig. 5, details of the RBC density distribution in one of the experiments reveal that a small fraction of RBCs incubated in gluca- mine media (at either $\mathrm{pH}$ ) became persistently very dense, as if these cells were least permeable to $\mathrm{NMG}^{+}$. Further study would be needed to resolve these possibilities.

In one experiment SS cells from reticulocyte-rich density fractions were suspended in solution $\mathrm{D}(\mathrm{pH} 7.4)$, with and without $0.1 \mathrm{mM}$ bumetanide (a known inhibitor of the $\mathrm{Na}: \mathrm{K}: 2 \mathrm{Cl}$ cotransport), and incubated for $2 \mathrm{~h}$ at $37^{\circ} \mathrm{C}$. No difference was detected in the density distribution of the cells before and after incubation, with or without bumetanide. This result argues against significant participation of a $\mathrm{Na}: \mathrm{K}: 2 \mathrm{Cl}$ cotransport in the volume balance of SS reticulocytes.

The proportion of SS cells from each density fraction capable of dehydration by combined acidification and external $\mathrm{Na}^{+}$ replacement is shown in the experiment of Table VI. After $1 \mathrm{~h}$ of incubation in these conditions, roughly similar proportions of cells from each of the three fractions investigated underwent some dehydration, while $>80 \%$ of the cells in each fraction behaved in this respect like normal mature RBCs and did not dehydrate. With this blood sample the cells from the upper discocyte fraction that increased in density were considerably enriched in reticulocytes; these could represent the expected cells with simultaneously preserved reticulum and young cell transport properties that have moved down from the lightest density fractions in the process of becoming dense SS RBCs.

To see if the reported low magnesium content of dense SS RBCs (16) could be traced to the fraction of cells that would dehydrate in low $\mathrm{Na}^{+}$, low $\mathrm{pH}$ media, we measured the total cell magnesium in each cell density fraction. As seen in Table VI, magnesium decreased slightly with increasing cell density, and within each density fraction those cells that shrank after $\mathrm{Na}^{+}$replacement and acidification contained less magnesium than those that did not dehydrate.

This experiment demonstrates that many morphologically recognizable SS reticulocytes either lack or have lost the transport properties that mediate dehydration in low $\mathrm{Na}^{+}$, low $\mathrm{pH}$ media. Conversely, among the cells in each discocyte density fraction exhibiting those transport properties and capable of

Table V. Effects of Medium Acidification and $\mathrm{Na}^{-}$Replacement on the Density of Reticulocyte-rich SS RBCs

\begin{tabular}{|c|c|c|c|c|c|c|c|c|c|c|c|c|}
\hline \multirow[b]{3}{*}{ Time } & \multicolumn{12}{|c|}{ Percent RBCs attaining density exceeding original values specified } \\
\hline & \multicolumn{4}{|c|}{ Experiment I (density exceeded 1.091) } & \multicolumn{4}{|c|}{ Experiment II (density exceeded 1.087) } & \multicolumn{4}{|c|}{ Experiment III (density exceeded 1.091) } \\
\hline & $\mathbf{N a}$ & NGM & $\mathrm{Na}$ & NMG & $\mathrm{Na}$ & NMG & $\mathrm{Na}$ & NMG & $\mathrm{Na}$ & NMG & $\mathrm{Na}$ & NMG \\
\hline \multicolumn{13}{|l|}{$\min$} \\
\hline $\mathbf{0}$ & 0 & 0 & 0 & 0 & $\mathbf{0}$ & 0 & 0 & 0 & 0 & 0 & 0 & 0 \\
\hline 15 & 2.5 & 2.9 & 0 & 0.6 & 22 & 15 & - & 6.0 & 14 & 9.6 & 0 & 19 \\
\hline 30 & 6.6 & 6.2 & 0 & 0.8 & 38 & 25 & - & 11 & 19 & 23 & 0 & 22 \\
\hline 45 & 9.2 & 8.2 & 0 & 0.7 & 39 & 29 & - & 5.0 & - & - & - & - \\
\hline 60 & 11 & 10 & 0 & 1.0 & 42 & 30 & - & 5.0 & 34 & 36 & - & 12 \\
\hline 120 & - & - & - & - & 41 & 33 & 2.0 & 7.0 & - & - & - & - \\
\hline
\end{tabular}

SS RBCs with maximum densities of 1.087 or 1.091 and $49-52 \%$ reticulocytes were suspended at $2 \%$ Hct in either high $\mathrm{Na}^{+}$media (Na, solution $\mathrm{D}$ ) or in glucamine media (NMG) at pH 7.0 or 7.4 , and incubated at $37^{\circ} \mathrm{C}$. In experiment I the glucamine media differed from the one listed in Methods by containing $125 \mathrm{mM} \mathrm{NMG}^{+}$and $20 \mathrm{mM} \mathrm{NaCl}$ rather than $145 \mathrm{nM} \mathrm{NMG}{ }^{+}$. At the times indicated $0.5-\mathrm{ml}$ aliquots of suspension were taken to examine the RBC density distribution using solutions of Stractan (see Fig. 5 legend). The percent of RBCs whose density exceeded the initial maximum is shown in the table, whereas full details of the RBC density distribution of each timed sample taken in experiment II are shown in Fig. 5. 


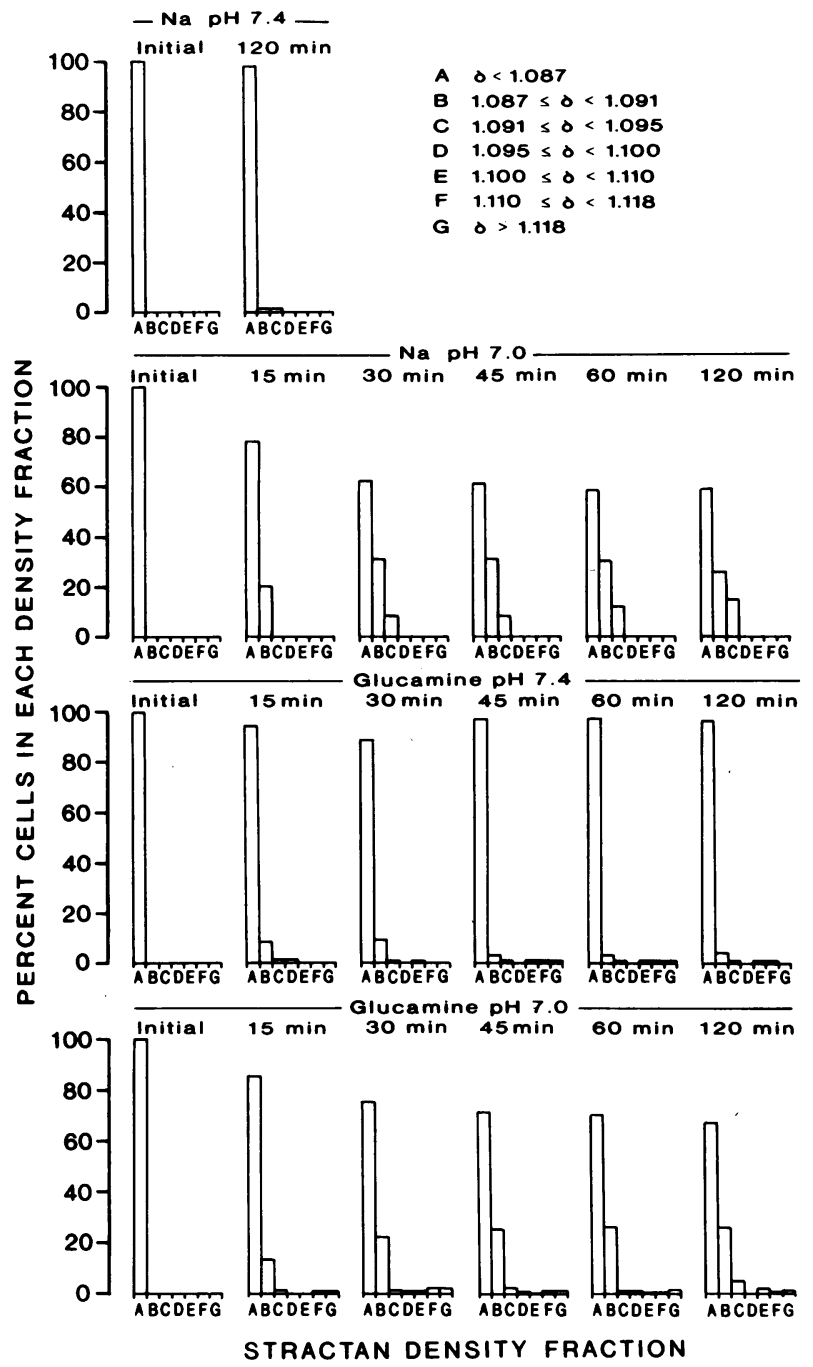

Figure 5. Effects of acidification and $\mathrm{Na}^{+}$replacement by $\mathrm{NMG}^{+}$on the density distribution of a light, reticulocyte-rich fraction of SS RBCs. An RBC fraction with density $\delta \leq 1.087$, containing $52 \%$ reticulocytes, was suspended at $2 \%$ Hct in either solution D (with plasma levels of sodium) or "glucamine medium," at pH either 7.4 or 7.0 at $37^{\circ} \mathrm{C}$. At the times shown, $0.5-\mathrm{ml}$ aliquots of RBC suspension were layered onto $0.5-\mathrm{ml}$ Stractan solutions of different densities in 1.5-ml plastic tubes. After 2 min centrifugation at $12,000 \mathrm{rpm}$ in an Eppendorf microcentrifuge the $\mathrm{Hb}$ content in the pellet was measured and expressed as a percentage of the total $\mathrm{Hb}$ in the aliquot. Some of these results are summarized in Table II (as experiment II) for comparison with two similar experiments.

shrinking in this media, there are some that have lost the reticular material.

Distribution of $\mathrm{Hb} F$ in SS cell density fractions before and after dehydration by acidification or deoxygenation in the presence of $\mathrm{Ca}^{2+}$. The experiments shown in Table VII were done to examine the possible relevance of the proportion of $\mathrm{Hb} \mathrm{F}$ in the SS RBCs to their propensity to dehydrate when induced either by activation of the $\mathrm{K}: \mathrm{Cl}$ cotransport by acidification or by deoxygenation in the presence of $\mathrm{Ca}^{2+}$. It should be kept in mind that in the absence of concomitant hereditary persistence of fetal $\mathrm{Hb}$, the $\mathrm{Hb} \mathrm{F}$ is virtually all localized in " $\mathrm{F}$ cells," and differences in the distribution of $\mathrm{Hb} F$ in different cell fractions reflects the distribution of these high F RBCs and reticulocytes $(5,17)$.

As first shown by Bertles and Milner (5), the proportion of $\mathrm{Hb} F$ was much lower in both the lightest SS cells, highly enriched in reticulocytes, and the dense cell fractions, comprising primarily ISCs, than in the SS discocyte fractions. After 30 min incubation at $\mathrm{pH} 7.0$ the newly dehydrated cells from the reticulocyte-rich fraction showed only a small further reduction in the proportion of $\mathrm{Hb} \mathrm{F}$, from 4.5 to $3.3 \%$ (mean values of the four experiments in Table VII in which the density of the original light fractions was $\leq 1.087$ ); but the discocyte fractions, in which mean $\mathrm{Hb} \mathrm{F}$ levels were enriched to $11.4 \%$, yielded dense cell fractions whose mean $\mathrm{Hb} F$ levels were markedly reduced, to $5.3 \%$. A pattern similar to these discocyte fractions was seen with the "retic" fraction in the experiment with donor P.H.: this "retic" fraction included denser cells $(\delta \leq 1.091)$ than the others, had only $30 \%$ reticulocytes, and the initial $\mathrm{Hb} \mathrm{F}$ of the light fraction was as high as in the discocyte fractions; but the cells that showed an increased density after incubation at $\mathbf{p H} 7.0$ were virtually all reticulocytes, and their mean $\mathrm{Hb}$ F level was only $5.3 \%$, similar to the acid-densified cells in the other experiments. Thus, among most of the high $F$ cells enriched in the discocyte fraction, the $\mathrm{K}: \mathrm{Cl}$ cotransport could not be activated by lowered $\mathrm{pH}$. On the other hand, since there was little depletion of F cells among the light cells undergoing acid-induced dehydration, the presence of a large proportion of $\mathrm{Hb} \mathrm{F}$ in the cell does not, per se, appear to inhibit acid activation of the $\mathrm{K}: \mathrm{Cl}$ cotransport. Rather, the high $\mathrm{F}$ cells may have a longer survival for other reasons (e.g., inhibition of $\mathrm{Hb} \mathrm{S}$ polymerization), so that more of them enter the discocyte fraction and have "outgrown" their $\mathrm{K}: \mathrm{Cl}$ cotransport features. Those cells in the discocyte fraction that dehydrate at lowered $\mathrm{pH}$ may thus retain an active acid-stimulated $\mathrm{K}: \mathrm{Cl}$ cotransport by virtue of their young age, as suggested by the marked enrichment of reticulocytes among the discocytes that increase in density at $\mathrm{pH} 7.0$; their presence in the middle density "discocyte" fraction could reflect their partial dehydration and downward descent towards the dense cell fraction.

As seen in other experiments, deoxygenation resulted in substantial proportions of denser cells only with the original light "retic" fractions, and it was primarily the reticulocytes that increased in density. The marked depletion of $\mathrm{Hb} F$ among these newly denser cells is consistent with the partial inhibition of sickling in the high F cells.

\section{Discussion}

The hypothesis of a direct reticulocyte origin of ISCs and other dense SS RBCs was based partly on the predictions of the reticulocyte model developed in the previous paper. According to that model, the mutual cause-effect relationship between acidification and dehydration in reticulocytes should result in progressive dehydration following either initial slight acidification or dehydration due to net loss of $\mathrm{KCl}$. The present experiments, by demonstrating that SS reticulocytes are susceptible to much more rapid dehydration than the discocytes when deoxygenated in physiological conditions in the presence of $\mathrm{Ca}^{2+}$, establish the feasibility of sickling as an important trigger and part of a continued positive feedback mechanism in this process. In addition, they provide evidence for several predic- 
Table VI. Reticulocyte Distribution and Magnesium Content of SS RBC Density Fractions Incubated at pH 7.0 in Glucamine Media

\begin{tabular}{|c|c|c|c|c|c|c|c|c|c|}
\hline \multirow[b]{3}{*}{$\begin{array}{l}\text { Initial density } \\
\text { fractions }\end{array}$} & \multicolumn{3}{|c|}{ Initial values } & \multicolumn{6}{|c|}{ Final values after incubation } \\
\hline & \multirow[b]{2}{*}{$\begin{array}{l}\text { Cells in } \\
\text { fraction }\end{array}$} & \multirow[b]{2}{*}{ Reticulocytes } & \multirow[b]{2}{*}{$\begin{array}{c}\text { Cell } \\
{\left[\mathrm{Mg}^{\mathrm{T} *}\right.}\end{array}$} & \multicolumn{3}{|c|}{ RBCs with density unchanged } & \multicolumn{3}{|c|}{ RBCs with density increased } \\
\hline & & & & Cells & Reticulocytes & $\begin{array}{c}\text { Cell } \\
{\left[\mathbf{M g}^{\mathrm{T}}\right.}\end{array}$ & Cells & Reticulocytes & $\begin{array}{c}\text { Cell } \\
{\left[\mathrm{Mg}^{\mathrm{T}}\right.}\end{array}$ \\
\hline & \multicolumn{2}{|c|}{ \% } & & \multicolumn{2}{|r|}{ \% } & & \multicolumn{2}{|c|}{$\%$} & \\
\hline Whole blood & 100 & 15 & 2.70 & - & - & - & - & - & - \\
\hline Retic & 27 & 38 & 3.84 & 83 & 40 & 3.91 & 17 & 32 & 3.19 \\
\hline Disc I & 23 & 11 & 2.59 & 88 & 6 & 2.63 & 12 & 25 & 2.38 \\
\hline Disc II & 40 & 5 & 2.45 & 82 & 4 & 2.43 & 18 & 5 & 2.25 \\
\hline ISC & 10 & 1 & 2.12 & - & - & - & - & - & - \\
\hline
\end{tabular}

SS RBCs were separated on discontinuous Stractan gradients into four groups with the following densities: retic, $\delta \leq 1.091$; disc I, $1.091<\delta$ $\leq 1.095$; disc II, $1.095<\delta \leq 1.118$; and ISC, $\delta>1.118$. After incubating the upper three fractions in glucamine media ( $\mathrm{Na}^{+}$replaced by $\mathrm{NMG}^{+}$) at $\mathrm{pH} 7.0$ for $1 \mathrm{~h}$ at $37^{\circ} \mathrm{C}$, the RBCs whose density exceeded the initial maximum in each group were separated from the rest using the appropriate Stractan solutions. * Total cell magnesium, mmol/340 g Hb.

tions of the model and the hypothesis, such as the need for a high $\mathrm{Na}^{+}$influx to maintain a normal reticulocyte volume, and the conservation of young cell transporters among relatively dense reticulocytes, as expected for transitional cells.

An important consideration in the detailed analysis of these results, however, is the impurity and heterogeneity of reticulocyte preparations obtained by density separation, since this bears on the generality of the conclusions. Apart from the expected age heterogeneity, the data reveal a dissociation between morphological and functional "reticulocytes," i.e., between cells with ion transport properties observed only in young circulating RBCs, and reticulocytes identifiable by the

Table VII. Percent Hb F and Reticulocytes before and after Medium Acidification or Deoxygenation of Density-fractionated SS RBCs

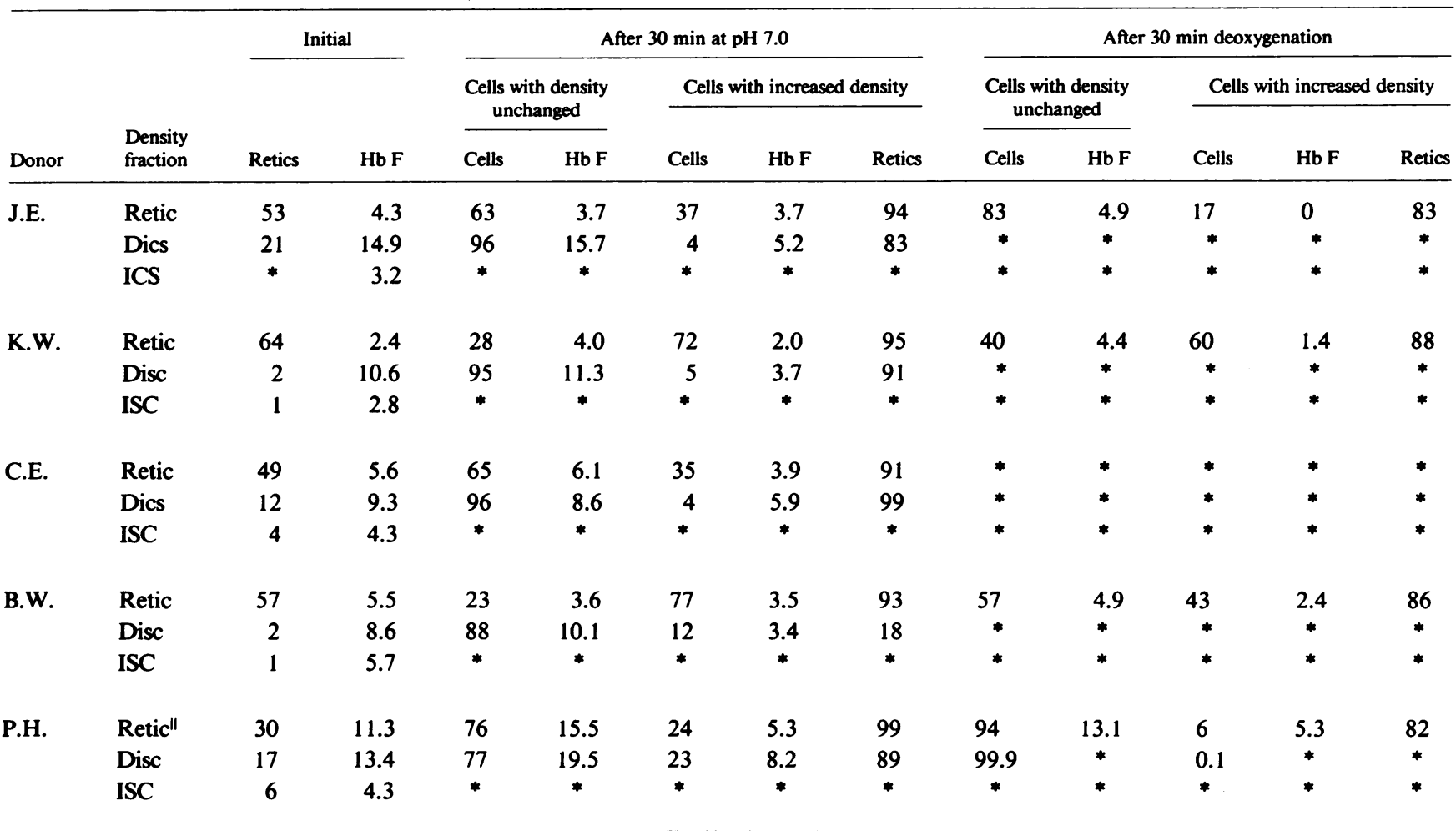

All data (cells, reticulocytes, and $\mathrm{Hb}$ F) expressed as percent of the total. Five groups of SS RBCs were isolated on discontinuous Stractan gradients: retic, $\delta \leq 1.087$ (except for donor PH, where the retic fraction marked II included all RBCs with $\delta \leq 1.091$ ); disc, $1.095<\delta \leq 1.110$; and ISC, $\delta>1.118$. After incubating the upper two fractions for $30 \mathrm{~min}$ in isotonic high $\mathrm{Na}^{+}$buffer (solution D) at $37^{\circ} \mathrm{C}$, either oxygenated at pH 7.0 or deoxygenated at pH 7.4, the RBCs whose density exceeded the initial maximum in each group were separated from the rest using the appropriate Stractan solutions. * Not done. 
usual supravital staining methods, but without significant activity of young cell transporters. The data suggest that loss of the reticular morphology and the various transporters on maturation proceed at unrelated rates in different subpopulations of young SS cells. In addition, the fraction of reticulocytes responding to the various experimental maneuvers performed in these studies varied in different patients, and sometimes in cells from the same patient on different days, although some patterns of response seemed conserved when the experimental conditions were strictly comparable (see Table I). Because of this heterogeneity and variability, the results, particularly those concerned with experimental tests of reticulocyte model predictions, must be interpreted with less generality and precision than those reported for homogeneous populations of mature RBCs $(6,18)$.

Test of the reticulocyte models' predictions of a $\mathrm{Na}^{+}$influx mechanism. The observed dehydration of variable fractions of light SS RBCs when incubated in the oxygenated state in glucamine media (at normal $\mathrm{pH}$ ), as seen in Table $\mathrm{V}$, is consistent with the predicted requirement of a high $\mathrm{Na}^{+}$influx to maintain the normal volume of reticulocytes (1). The pattern of cell dehydration upon incubation at pH 7.0 (Fig. 5 and Table V) suggests that the high $\mathrm{Na}^{+}$influx is not mediated predominantly by a $\mathrm{pH}_{\mathrm{i}}$-modulated $\mathrm{Na}: \mathrm{H}$ exchange, since this model option predicts cell swelling at pH 7.0 ([1], their Fig. $4 \mathrm{~B}$ ). However, reticulocytes may vary considerably in their transport properties and it is possible that some of the cells that did not dehydrate swelled at acid $\mathrm{pH}$, due to a $\mathrm{Na}: \mathrm{H}$ exchange. Further experiments will be needed to assess the heterogeneity of $\mathrm{Na}^{+}$entry paths in reticulocytes.

Effects of deoxygenation on light SS cells: feasibility of the hypotheses on a direct reticulocyte origin of ISCS. Whereas with SS discocytes prolonged alternating oxygenation/deoxygenation protocols were necessary to elicit $\mathrm{Ca}^{2+}$-dependent net cation loss and dense cell formation (19-22), a single deoxygenation pulse in normal plasma caused a variable but significant fraction of light cells, mostly with reticular morphology, to become highly permeable to cations and sustain an increase in density within $30 \mathrm{~min}$ or less. A fraction of reticulocytes and other light SS cells must therefore be susceptible to rapid dehydration upon deoxygenation in the circulation.

In view of the steep concentration dependence of $\mathrm{Hb} \mathrm{S}$ polymerization (23) it was surprising that on deoxygenation the light cells, whose $\mathrm{Hb}$ concentrations are lowest, should show the largest increases in cation permeability. That the intensity of the permeabilization induced by sickling may not relate directly to the fraction of $\mathrm{Hb} \mathrm{S}$ that participates in polymer formation, particularly among cells that are dense and dehydrated, was suggested by Mohandas et al. (24). They observed decreased sickling-induced $\mathrm{K}^{+}$fluxes after hypertonic dehydration of SS discocytes and concluded that the spicules resulting from aligned polymers, which formed preferentially at the lower $\mathrm{Hb}$ concentrations, were more permeabilizing than the nonaligned polymer masses that tended to form at higher $\mathrm{Hb}$ concentrations (25) and which did not produce long spicules. Further work on the comparative morphology of reticulocytes that become dense or stay light after deoxygenation should help test the extent to which spikes relate to permeabilization.

Because of their large permeability changes on deoxygenation, the light SS cell fractions are particularly well suited for investigating the sickling-induced permeabilizing injury. Although the nature of this injury is still unknown, the present results define some of its main functional properties in light SS cells: (a) When the RBCs are suspended in low $\mathrm{Ca}^{2+}$ serum or plasmalike buffers (with excess EGTA), deoxygenation increases the $\mathrm{Na}^{+}$and $\mathrm{K}^{+}$permeability leading to gradient dissipation; $\mathrm{Na}^{+}$gain generally balances $\mathrm{K}^{+}$loss, with little cell volume change. (b) The deoxygenation-induced $\mathrm{Na}^{+}$and $\mathrm{K}^{+}$ fluxes are generally much larger in the lighter cell fractions than in the relatively denser discocyte fractions of the same SS blood sample. $(c)$ With the light cell fraction, the presence of normal serum $\mathrm{Ca}^{2+}$ has two major effects on those fluxes-a reduction in their absolute size, and an altered balance-so that $\mathrm{K}^{+}$efflux exceeds $\mathrm{Na}^{+}$influx, with net loss of total cation. At least part of this imbalance is attributable to activation of a quinine-inhibitable, $\mathrm{Ca}^{2+}$-dependent $\mathrm{K}$ flux. $(d)$ As with SS discocytes and AS RBCs (heterozygous for $\mathrm{Hb} \mathrm{S}$ ) (26), light SS RBCs are also permeabilized to $\mathrm{Ca}^{2+}$ by deoxygenation. $(e)$ in serum or plasmalike buffer with normal $\mathrm{Ca}^{2+}$ levels, deoxygenation induces substantial dehydration within 30 min only among cells in the light fractions; the population of newly formed dense cells is variably enriched in reticulocytes and excludes most of the cells with high levels of $\mathrm{Hb} \mathrm{F}$; the densest of these newly dense cells includes some with a morphology resembling ISCs.

These results demonstrate that a fraction of light SS cells, mostly reticulocytes, is susceptible to rapid dehydration after deoxygenation in physiological conditions. This process could lead to the formation of increasingly dense young cells (with or without reticulum), which soon after would become the densest cells (including morphological ISCs) that no longer contain reticulum. Direct ISC formation from a subpopulation of vulnerable reticulocytes therefore represents a viable working hypothesis.

At present we can only speculate about the factors determining the susceptibility of certain light, young SS RBC to rapid dehydration. Observations that the fraction of ISCs or dense cells in each patient is fairly constant in the steady state between crises $(27,28)$ suggest that there might be similarly constant fractions of reticulocytes susceptible to dehydration. Since polymerization of $\mathrm{Hb} \mathrm{S}$ is inhibited in high $\mathrm{F}$ cells, $\mathrm{F}$ reticulocytes should be relatively excluded from the susceptible population if sickling is a necessary step. Other factors that determine steady fractions of ISCs in individual patients might include differences in the numbers of $\mathrm{Ca}^{2+}$ pumps, $\mathrm{Ca}^{2+}$-sensitive $\mathrm{K}^{+}$or $\mathrm{Cl}^{-}$channels (29), or $\mathrm{K}: \mathrm{Cl}$ cotransporters per cell. It seems less likely that the observed constancy may result from stochastic factors, such as individual variations in the frequency, duration, and intensity of sickling-induced $\mathrm{Ca}^{2+}$ permeabilization among young cells.

These experiments also demonstrated two new properties of the sickling-induced cation leak in SS reticulocytes under certain nonphysiological conditions. One is a much larger sickling-related leak of $\mathrm{Na}^{+}$and, to a variable extent, of $\mathrm{K}^{+}$in the absence of external $\mathrm{Ca}^{2+}$. Since sickling increases $\mathrm{Ca}^{2+}$ permeability in the reticulocytes, the present data do not distinguish between effects of large (physiological) amounts of $\left[\mathrm{Ca}^{2+}\right]_{\mathrm{o}}$ and small increases in $\left[\mathrm{Ca}^{2+}\right]_{i}$, in the nanomolar range. Further experiments with SS reticulocytes loaded with Ca chelators should resolve this question. A second new property is the marked increase in the sickling-induced $\mathrm{Na}^{+}$and $\mathrm{K}^{+}$leaks 
in SS reticulocytes in the presence of heparin. Investigation of this effect may provide further clues about the mechanism of the permeabilization and will be the subject of separate studies.

The mechanism of rapid dehydration of young SS cells. One possible mechanism of formation of ISCs and other dense SS cells, derived from the analysis of reticulocyte models (1), was that a fraction of vulnerable reticulocytes, upon deoxygenation and sickling, would increase their $\left[\mathrm{Ca}^{2+}\right]_{i}$ levels enough to activate $\mathrm{K}^{+}$channels and thus trigger $\mathrm{K}^{+}$and $\mathrm{Cl}^{-}$ loss, cell dehydration, and slight acidification (1). Since the $\mathrm{K}: \mathrm{Cl}$ cotransport is highly $\mathrm{pH}$ sensitive in the physiological range, further dehydration and acidification would follow. The experimental results, that rapid dehydration of young cells upon deoxygenation is strictly $\mathrm{Ca}^{2+}$-dependent, demonstrate that the hypothesis is plausible but do not yet prove that the cells dehydrate by that mechanism.

There are two possible triggers for the initial dehydration of SS reticulocytes. One is acidification, which was also shown by Brugnara et al. (2) to dehydrate oxygenated (or carbon monoxide-equiilibrated) cells from the light and middle density fractions of SS blood; the other is deoxygenation-induced $\mathrm{Ca}^{2+}$ permeabilization. Transient acidification of any cell with a large number of $\mathrm{pH}_{\mathrm{i}}$-sensitive $\mathrm{K}: \mathrm{Cl}$ cotransporters could result in dehydration, without deoxygenation or sickling. $\mathrm{Ca}^{2+}$-induced dehydration, on the other hand, requires a $\mathrm{Ca}^{2+}$-permeabilizing event such as sickling, since the membrane has a low $\mathrm{Ca}^{2+}$ permeability and a large capacity $\mathrm{Ca}^{2+}$ extrusion pump $(30,31) . \mathrm{Ca}^{2+}$-dependent dehydration may proceed by two pathways: directly, by activation of $\mathrm{K}^{+}$- and $\mathrm{Cl}^{-}$-selective channels $(29,32)$, and indirectly, by secondary acidification and activation of $\mathrm{K}: \mathrm{Cl}$ transporters, as shown by model analysis (1).

The earlier findings of Bertles and Milner, that the proportion of $\mathrm{Hb} \mathrm{F}$ was low in the dense ISCs (5), could be simply explained if polymerization of deoxy $\mathrm{Hb} \mathrm{S}$ played an important role in the dehydration process. The results described above confirm a low frequency of high $F$ cells in both the lightest and densest SS cell fractions, and enrichment of F cells in the discocyte fraction. The additional findings, that the $F$ cells in the light fraction are not excluded from dehydration induced by low $\mathrm{pH}$, suggest that $\mathrm{Hb} \mathrm{F}$ does not inhibit acidactivation of the $\mathrm{K}: \mathrm{Cl}$ cotransport. This reinforces the likelihood that $\mathrm{Hb} \mathrm{S}$ polymerization and sickling are important initiating factors in dehydration of the SS reticulocytes. Within the middle density discocyte fraction, the cells that dehydrate at low pH have low $\mathrm{F}$ cell proportions similar to the light fraction and are highly enriched in reticulocytes. This is consistent with the possibility that these are mostly low F reticulocytes "on their way down" to becoming ISCs and other dense SS cells. The present findings can account for the reported observation that the fraction of SS discocytes that are volume sensitive is similarly lower in $\mathrm{Hb} F$ than the mean value for the discocytes (33).

We analyze next the possible contributions of the two triggering mechanisms. Although $\mathrm{Ca}^{2+}$-independent acidification in the circulation (without deoxygenation) could act as a trigger, the distribution of $F$ cells described above supports the idea that deoxygenation-induced sickling, and not solely acidstimulated activation of the $\mathrm{K}: \mathrm{Cl}$ cotransport in the oxygenated SS cells, is important in the early stages of SS cell dehydration. Furthermore, RBCs ordinarily become partially deoxygenated at the same time as they acidify. Whenever acidification results from local circulatory stasis, deoxygenation and sickling-induced $\mathrm{Ca}^{2+}$ permeabilization are also likely. On the other hand, increased $\mathrm{Ca}^{2+}$ permeability may occur in the partially deoxygenated venous circulation without additional acidification of the local plasma. The progressive accumulation of total calcium in all SS cell density fractions is positive evidence of past episodes of increased $\mathrm{Ca}^{2+}$ permeability, since accumulation is the result of ATP-dependent trapping within endocytic vesicles (34), and increased calcium accumulation must follow from elevated $\left[\mathrm{Ca}^{2+}\right]_{\mathrm{i}}$. Vesicular calcium accumulation per se does not tell whether the increased $\left[\mathrm{Ca}^{2+}\right]_{i}$ was high and prolonged enough to dehydrate the cells by activation of $\mathrm{K}^{+}$channels and $\mathrm{Cl}^{-}$channels. But recent experiments suggest that a rise in $\left[\mathrm{Ca}^{2+}\right]_{i}$ from normal values of $\sim 10-30$ to $40-50 \mathrm{nM}$ may suffice to trigger dehydration in normal RBCs (35).

Although the present experiments show that external acidification and $\mathrm{Na}^{+}$replacement led to dehydration of many cells in the middle, discocyte fraction as well as in the lightest fraction of SS cells, earlier results (36-38), confirmed here, indicate that deoxygenation of the SS discocyte fractions in the presence or absence of $\mathrm{Ca}^{2+}$ did not rapidly dehydrate any cells. It follows that those cells within the discocyte fraction that retain the ability to dehydrate by external acidification and $\mathrm{Na}^{+}$replacement have lost or lacked the ability of a large fraction of light cells to rapidly dehydrate when deoxygenated in the presence of $\mathrm{Ca}^{2+}$.

Within the constraints of these results, it is possible to outline a modified working hypothesis on the origin of ISCs and other dense SS cells. These would arise primarily from a susceptible young subpopulation of SS RBCs, which excludes the high F cells in which $\mathrm{Hb}$ polymerization is inhibited. Repeated partial deoxygenation in the circulation would initiate dehydration of these susceptible cells, generating somewhat denser young cells, many of which may still retain reticular material. The initial dehydration would be $\mathrm{Ca}^{2+}$ dependent, resulting from activation of $\mathrm{K}^{+}$and $\mathrm{Cl}^{-}$channels, but not necessarily $\mathrm{K}: \mathrm{Cl}$ transporters. Among these dehydrated, slightly acidified young cells, those retaining functional $\mathrm{K}: \mathrm{Cl}$ cotransporters would continue to dehydrate regardless of their state of oxygenation. By the time they attain the high density of ISCs, most would have lost the reticulum and the activity of all young cell transporters. Nonsusceptible reticulocytes and young cells, on the other hand, would mature further to discocytes, exposed to slow $\mathrm{Ca}^{2+}$-dependent dehydration by repeated deoxygenation in the circulation $(19,39)$. This would generate the observed heterogeneity of cell densities, with a fraction of young cells dehydrating faster than the rest within each density fraction.

Further work will be needed to investigate the transport options represented in SS reticulocytes, to identify the traits that select the cells susceptible to rapid dehydration, and to establish the relative importance of $\mathrm{Ca}^{2+}$-dependent and -independent triggers of young cell dehydration.

\section{Acknowledgments}

We wish to thank the Wellcome Trust of Great Britain and the National Institutes of Health (grants HL-28018 and HL-21016) for funds. 


\section{References}

1. Lew, V. L., C. J. Freeman, O. E. Ortiz, and R. M. Bookchin. 1990. A mathematical model of the volume, pH, and ion content regulation in reticulocytes. Application to the pathophysiology of sickle cell dehydration. J. Clin. Invest. 86:100-112.

2. Brugnara, C., H. F. Bunn, and D. C. Tosteson. 1986. Regulation of erythrocyte cation and water content in sickle cell anemia. Science (Wash. DC). 232:388-390.

3. Brugnara, C., and D. C. Tosteson. 1987. Inhibition of K transport by divalent cations in sickle erythrocytes. Blood. 70:1810-1815.

4. Brugnara, C., T. V. Ha, and D. C. Tosteson. 1989. Acid pH induces formation of dense cells in sickle erythrocytes. Blood. 74:487495.

5. Bertles, J. F., and P. F. A. Milner. 1968. Irreversibly sickled erythrocytes. A consequence of the heterogeneous distribution of hemoglobin types in sickle cell anemia. J. Clin. Invest. 47:1731-1741.

6. Freeman, C. J., R. M. Bookchin, O. E. Ortiz, and V. L. Lew. 1987. K-permeabilized human red cells lose an alkaline, hypertonic fluid containing excess $\mathrm{K}$ over diffusible anions. J. Membr. Biol. 96:235-241.

7. Lew, V. L., C. J. Freeman, O. E. Ortiz, and R. M. Bookchin. 1988. A new hypothesis on the origin of irreversibly sickled cells: predictions from an integrated reticulocyte model. Clin. Res. 36:567A. (Abstr.)

8. Ortiz, O. E., V. L. Lew, and R. M. Bookchin. 1986. Calcium accumulated by sickle cell anemia red cells does not affect their potassium $\left({ }^{86} \mathrm{Rb}\right)$ flux components. Blood. 67:710-715.

9. Corash, L. M., S. Piomelli, H. C. Chen, C. Seaman, and E. Gross. 1974. Separation of erythrocytes according to age on a simplified density gradient. J. Lab. Clin. Med. 84:147-151.

10. Danon, D., and Y. Marikovsky. 1964. Determination of the density distribution of red cell populations. J. Lab. Clin. Med. 64:668-674.

11. Lew, V. L., R. Y. Tsien, C. Miner, and R. M. Bookchin. 1982. The physiological $\left(\mathrm{Ca}^{2+}\right)$ level and pump-leak turnover in intact red cells measured with the use of an incorporated $\mathrm{Ca}$ chelator. Nature (Lond.). 298:478-481.

12. Tiffert, T., J. Garcia-Sancho, and V. L. Lew. 1984. Irreversible ATP depletion caused by low concentrations of formaldehyde and calcium-chelator esters in intact human red cells. Biochim. Biophys. Acta. 773:143-156.

13. Garcia-Sancho, J. 1985. Pyruvate prevents the ATP depletion caused by formaldehyde or calcium-chelator esters in the human red cell. Biochim. Biophys. Acta. 813:148-150.

14. Wiley, J. S., and C. C. Shaller. 1977. Selective loss of calcium permeability on maturation of reticulocytes. J. Clin. Invest. 59:11131119.

15. Lew, V. L., and H. G. Ferreira. 1978. Calcium transport and the properties of a calcium-activated potassium channel in red cell membranes. Curr. Top. Membr. Transp. 10:217-277.

16. Bookchin, R. M., O. E. Ortiz, and V. L. Lew. 1987. Red cell magnesium content and permeability in sickle cell anemia. Clin. Res. 35:651 A. (Abstr.)

17. Dover, G. J., S. H. Boyer, S. Charache, and K. Heintzelman. 1978. Individual variation in the production and survival of $F$ cells in sickle-cell disease. N. Engl. J. Med. 299:1428-1435.

18. Lew, V. L., and R. M. Bookchin. 1986. Volume, pH and-ion content regulation in human red cells: analysis of transient behavior with an integrated model. J. Membr. Biol. 92:57-74.

19. Bookchin, R. M., O. E. Ortiz, and V. L. Lew. 1986. Red cell calcium transport and mechanisms of dehydration in sickle cell anemia. In Approaches to the Therapy of Sickle Cell Anaemia. Y. Beuzard, S. Charache, and F. Galacteros, editors. INSERM, Paris. 291-299.
20. Bookchin, R. M., O. E. Ortiz, and V. L. Lew. 1987. Activation of calcium-dependent potassium channels in deoxygenated sickled red cells. In Pathophysiological Aspects of Sickle Cell Vaso-Occlusion. R. L. Nagel, editor. Alan R. Liss, Inc., New York. 193-200.

21. Ohnishi, S. T. 1983. Inhibition of the in vitro formation of irreversibly sickled cells by cepharanthine. Br. J. Haematol. 55:665671.

22. Ohnishi, S. T., K. Y. Horiuchi, and K. Horiuchi. 1986. The mechanism of in vitro formation of irreversibly sickled cells and modes of action of its inhibitors. Biochim. Biophys. Acta. 886:119-129.

23. Hofrichter, J., P. D. Ross, and W. A. Eaton. 1976. Supersaturation in sickle cell hemoglobin solutions. Proc. Natl. Acad. Sci. USA. 73:3035-3039.

24. Mohandas, N., M. E. Rossi, and M. R. Clark. 1986. Association between morphological distortion of sickle cells and deoxygenationinduced cation permeability increase. Blood. 68:450-454.

25. Asakura, T., and J. Mayberry. 1984. Relationship between morphologic characteristics of sickle cells and method of deoxygenation. J. Lab. Clin. Med. 104:987-994.

26. Bookchin, R. M., and V. L. Lew. 1981. Effect of a "sickling pulse" on calcium and potassium transport in sickle cell trait red cells. J. Physiol. (Lond.). 312:265-280.

27. Serjeant, G. R., B. E. Serjeant, and P. F. Milner. 1969. The irreversibly sickled cell: a determinant of haemolysis in sickle cell anaemia. Br. J. Haematol. 17:527-533.

28. Fabry, M. E., L. Benjamin, C. Lawrence, and R. L. Nagel. 1984. An objective sign in painful crisis in sickle cell anemia. The concomitant reduction of high density red cells. Blood. 64:559-563.

29. Ortiz, O. E., R. M. Bookchin, and V. L. Lew. 1988. A new method to measure the distribution of diffusional chloride $(\mathrm{Cl})$ permeabilities in the red cell populations reveals a $\mathrm{Ca}^{2+}$-sensitive $\mathrm{Cl}$ permeability in sickle cell anemia reticulocytes. Clin. Res. 36:415A. (Abstr.)

30. Ferreira, H. G., and V. L. Lew. 1977. Passive Ca transport and cytoplasmic Ca buffering in intact red cells. In Membrane Transport in Red Cells. J. C. Ellory and V. L. Lew, editors. Academic Press, NY. 53-91.

31. Schatzmann, H. J. 1982. The plasma-membrane calcium pump of erythrocytes and other animal cells. In Membrane Calcium Transport. E. Carafoli, editor. Academic Press Limited, London. 41-108.

32. Gardos, G. 1958. The function of calcium in the potassium permeability of human erythrocytes. Biochim. Biophys. Acta. 30:653654.

33. Fabry, M. E., J. R. Romero, R. L. Nagel, and M. Canessa. 1989. Sickle cells are heterogeneous in volume response: a mechanism for irreversibly sickled cells (ISC) formation. Clin. Res. 37:380A. (Abstr.)

34. Lew, V. L., A. Hockaday, M. I. Sepulveda, A. P. Somlyo, A. V. Somlyo, O. E. Ortiz, and R. M. Bookchin. 1985. Compartmentalization of sickle cell calcium in endocytic inside-out vesicles. Nature (Lond.). 315:586-589.

35. Tiffert, T., J. L. Spivak, and V. L. Lew. 1988. Magnitude of calcium influx required to induce dehydration of normal human red cells. Biochim. Biophys. Acta. 943:157-165.

36. Tosteson, D. C., E. Carlsen, and E. T. Dunham. 1955. The effects of sickling on ion transport. I. Effect of sickling on potassium transport. J. Gen. Physiol. 39:31-53.

37. Tosteson, D. C., E. Shea, and R. C. Darling. 1952. Potassium and sodium of red blood cells in sickle cell anemia. J. Clin. Invest. 31:406-411.

38. Bookchin, R. M., and V. L. Lew. 1983. Red cell membrane abnormalities in sickle cell anemia. Prog. Hematol. 13:1-23.

39. Gupta, R. K., and F. A. X. Schanne. 1986. ${ }^{19}$ F NMR measurements of intracellular free calcium in human red cells. Fed. Proc. 45:549. (Abstr.) 